Review

\title{
The Role of Exercise Testing in the Modern Management of Pulmonary Arterial Hypertension
}

\section{Martin K. Johnson * and Stephen Thomson}

Scottish Pulmonary Vascular Unit, Golden Jubilee National Hospital, Agamemnon Street, Clydebank G814DY, UK; E-Mail: stephenthomson1@nhs.net

*Author to whom correspondence should be addressed; E-Mail: mjohnson4@nhs.net; Tel.: +44-0-141-951-5497; Fax: +44-0-141-951-5948.

Received: 12 April 2014; in revised form: 28 April 2014 / Accepted: 30 April 2014 /

Published: 28 May 2014

\begin{abstract}
A culture of exercise testing is firmly embedded in the management of pulmonary arterial hypertension (PAH) but its clinical relevance and utility have recently been under some debate. The six minute walk test (6MWT) has been used as a primary outcome measure to enable the licensing of many of the medications used for this condition. Recent reviews have questioned the validity of this test as a surrogate of clinical outcomes. At the same time, other questions are emerging where exercise testing may be the solution. With the rise in understanding of genetic markers of idiopathic PAH (IPAH), the screening of an otherwise healthy population for incipient pulmonary hypertension $(\mathrm{PH})$ will be required. The proliferation in treatment choices and identification of populations with PH where PAH treatment is not indicated, such as left heart and lung disease, requires more definitive differentiation from patients with PAH. There is a continuing question about the existence and clinical relevance of exercise induced $\mathrm{PAH}$ as a cause of unexplained dyspnoea and fatigue and as a latent phase of resting PH. This review presents a summary and critical analysis of the current role of exercise testing in $\mathrm{PAH}$ and speculates on future trends.
\end{abstract}

Keywords: pulmonary arterial hypertension; exercise testing; activity monitoring 


\section{Introduction}

Exercise can be viewed as the process of transferring oxygen from atmosphere to capillaries and its utilisation there by exercising muscles. The movement of oxygen from the lungs to the capillaries is a convective process described mathematically by the Fick equation which states

$$
\mathrm{VO}_{2}=\mathrm{CO} \times\left(\mathrm{C}_{a} \mathrm{O}_{2}-\mathrm{C}_{v} \mathrm{O}_{2}\right)
$$

where $\mathrm{VO}_{2}$ is oxygen uptake, $\mathrm{CO}$ is cardiac output and $\mathrm{C}_{\mathrm{a}} \mathrm{O}_{2}-\mathrm{C}_{\mathrm{v}} \mathrm{O}_{2}$ is the arteriovenous difference in oxygen content. This equation can be expanded as follows:

$$
V \mathrm{O}_{2}=\mathrm{SV} \times \mathrm{HR} \times \mathrm{Hb} \times\left(\mathrm{S}_{a} \mathrm{O}_{2}-\mathrm{S}_{v} \mathrm{O}_{2}\right)
$$

where $\mathrm{SV}$ is stroke volume, $\mathrm{HR}$ heart rate, $\mathrm{Hb}$ blood haemoglobin concentration and $\mathrm{S}_{\mathrm{a}} \mathrm{O}_{2}-\mathrm{S}_{\mathrm{v}} \mathrm{O}_{2}$ the difference in oxygen saturation between arterial and mixed venous blood. Severe exercise intolerance due to impairment of oxygen transport is a hallmark of pulmonary arterial hypertension (PAH) and the reasons for that are evident from inspection of the Fick equation. In subjects with PAH, maximum SV is severely reduced [1], peak predicted HR is often not reached [2], relative anaemia is a common finding [3] and desaturation on exercise is present in the majority of cases due to a combination of precipitate fall in mixed venous oxygen saturation $\left(\mathrm{S}_{\mathrm{v}} \mathrm{O}_{2}\right)$ and ventilation-perfusion mismatch [4].

There are other factors which can in general limit exercise such as ventilatory limitation and peripheral muscle dysfunction but their contribution to impairment of exercise capacity in PAH is less relevant. Ventilatory capacity can be reduced in $\mathrm{PAH}$, where mild obstruction and restriction have been found at rest $[5,6]$ and dynamic hyperinflation with reduced end exercise inspiratory capacity on exercise $[7,8]$. More striking in these patients is markedly increased ventilatory demand due to reduced ventilatory efficiency. The pathophysiological reasons for this can be illustrated by considering the ratio of ventilation $\left(\mathrm{V}_{\mathrm{E}}\right)$ to carbon dioxide production $\left(\mathrm{VCO}_{2}\right)$ which is given by the following expression derived from the Bohr equation:

$$
\frac{V_{E}}{V C O_{2}}=\frac{k}{P_{a} C O_{2} \times\left(1-\frac{V_{D}}{V_{T}}\right)}
$$

where $\mathrm{k}$ is a constant, $\mathrm{P}_{\mathrm{a}} \mathrm{CO}_{2}$ is the arterial carbon dioxide concentration and $\mathrm{V}_{\mathrm{D}} / \mathrm{V}_{\mathrm{T}}$ is the ratio of dead space to tidal volume. In PAH, inefficient ventilation, i.e., the requirement for a high ventilation to remove the carbon dioxide produced by respiration, is due to a combination of both increased dead space and a lowered set point for arterial carbon dioxide concentration [9]. Despite this reduced ventilatory capacity and increased demand, ventilatory limitation is said not to occur in PAH unless there is concomitant lung disease. Peripheral muscle dysfunction has been shown in PAH in the form of reduced capillary density and oxidative enzymes in muscle biopsies of these patients [10]. This abnormality can lead to impairment of extraction of oxygen from muscle capillaries and should be reflected in abnormally high values of $\mathrm{S}_{\mathrm{v}} \mathrm{O}_{2}$ at end-exercise [11]. However, data from studies in heart failure [12] and published in abstract form in PAH [13] suggest that this is not the case. Thus, although muscle dysfunction is present in PAH, the diffusion capacity for oxygen from the capillaries to the mitochondria still more than matches the reduced level of oxygen delivery to the capillaries. 
Since exercise limitation is present in the majority of patients with this condition, exercise testing has been widely used as a means of investigating its severity and assessing for change. The most commonly used tests have been incremental cardiopulmonary exercise tests (CPETs) and six minute walk tests (6MWTs) but these have both had their critics. When the former was used as the primary outcome measure in a trial of sitaxentan, it proved negative, whereas 6MWT, as the secondary outcome measure, was positive [14]. The failure of CPET to show a signal was attributed to its complexity and hence the quality of test performance [15]. Recently an attempt was made to quantify what proportion of the treatment effect of disease targeted therapy was captured by changes in 6MWT distance (6MWD) [16]. This proved surprisingly low at $22.1 \%$, supporting earlier studies which suggested that changes in 6MWD were not of prognostic value [17].

There is opportunity for development in the application of exercise testing techniques in PAH. There has been interest in both invasive and non-invasive measurements of exercise haemodynamics since this is one of the cardinal impairments of pathophysiology in this condition. Attempts have been made to enhance the value of CPET and 6MWT by modifications of protocol or measurement of additional variables. Finally studies are emerging of the use of activity monitoring in PAH under the premise that this test will more closely reflect clinical reality. The aim of this review is to summarise the current status of exercise testing in PAH and to highlight recent advances.

\section{Exercise Haemodynamics}

\subsection{Invasive Measurement}

The measurement of the pressure-flow behaviour of the pulmonary circulation during exercise by right heart catheterisation (RHC) continues to be of interest despite the invasive process involved $[1,18,19]$. It provides information which cannot be accurately acquired by other routes. Potential roles include differentiating between pulmonary venous and pulmonary arterial hypertension, investigation of exertional dyspnoea defying diagnosis by non-invasive tests and accurate assessment of treatment effect on pulmonary artery haemodynamics.

Mean pulmonary artery pressure (mPAP), CO, pulmonary vascular resistance (PVR) and pulmonary artery occlusion pressure (PAOP) are interlinked by the equation

$$
P V R=\frac{(m P A P-P A O P)}{C O} .
$$

Figure 1 contrasts the typical results seen for mean pulmonary artery pressure (mPAP) during exercise in healthy individuals and those with PAH. In health both MPAP and PAOP rise with exercise. The estimated range of normality for mPAP change on exercise is $0.5-3.0 \mathrm{mmHg} \cdot \mathrm{min} . \mathrm{L}^{-1}$ [20] whereas the normal range for PAOP change is less certain, one estimate being $0.3-1.93 \mathrm{mmHg} . \mathrm{min} . \mathrm{L}^{-1}$ [19]. During supine exercise PVR falls slightly [21,22] and $\mathrm{S}_{\mathrm{v}} \mathrm{O} 2$ falls from $75 \%$ at rest to $25 \%$ at maximal exercise [23]. By contrast in PAH there is a very steep rise in mPAP over a much more limited CO response. The data for PVR and PAOP in PAH are very limited. In the study by Janicki et al. [24] which included a mixture of subjects with PAH and pulmonary hypertension (PH) related to lung disease, PAOP rose from $8 \mathrm{mmHg}$ at rest to $18 \mathrm{mmHg}$ on exercise with PVR unchanged. As discussed earlier, there has been controversy over the $\mathrm{S}_{\mathrm{v}} \mathrm{O} 2$ values achieved at maximal exercise in PAH. In a recent study of patients with precapillary pulmonary hypertension the mean $\mathrm{S}_{\mathrm{v}} \mathrm{O} 2$ on maximal supine exercise was low at $22 \%[13]$. 
Figure 1. Mean data for healthy subjects taken from Kovacs et al. [22]. Mean data for subjects with pulmonary arterial hypertension (PAH) adapted from Provencher et al. [25]. Exercise performed in the supine position. mPAP: mean pulmonary artery pressure, PAOP: pulmonary artery occlusion pressure.

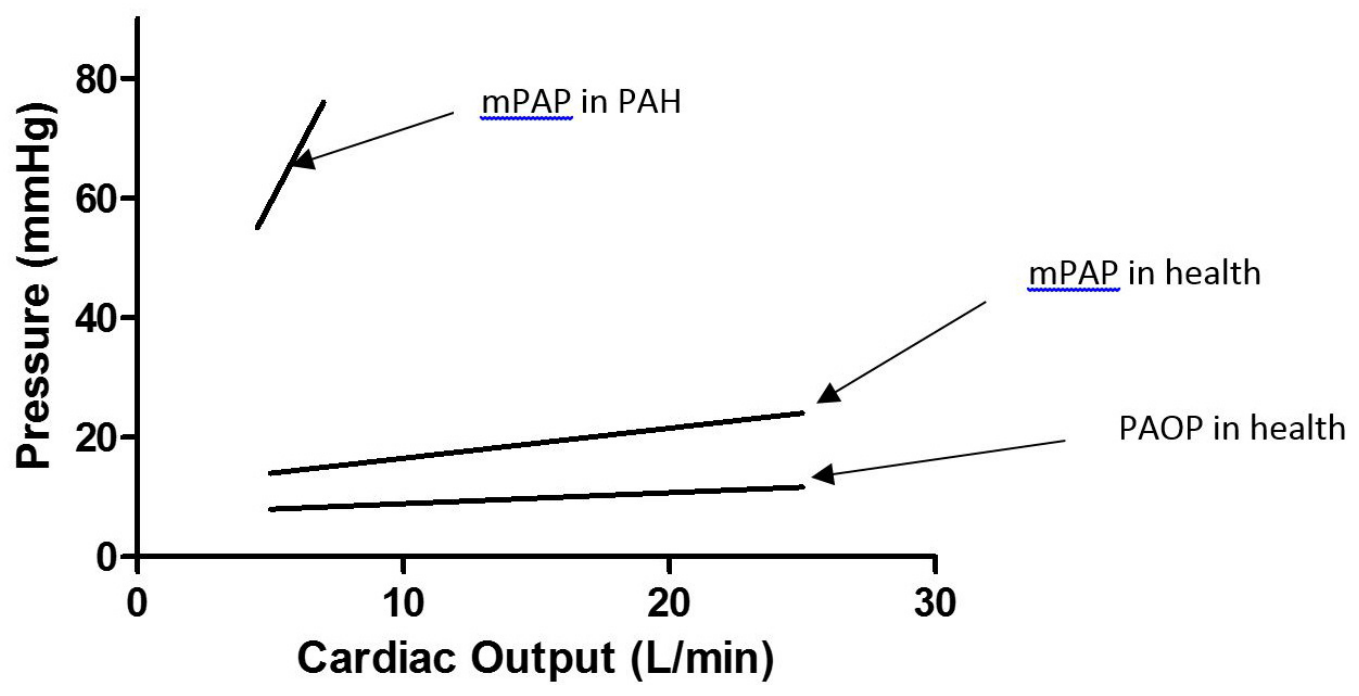

There are obvious issues with the widespread utilisation of exercise haemodynamics. Firstly, it is an invasive test and therefore not well suited to serial measurements. There is no standardised exercise protocol followed in the studies which have investigated its use [26]. Difficulties arise in interpreting measurements at peak exercise due to the swings in pressure traces caused by increasing respiratory efforts, particularly marked with PAOP [27] but also noticeable in mPAP (see Figure 2). To overcome this problem which leads to exaggerated end-expiratory pressures, it has been suggested that pulmonary vascular pressures measured during exercise should be averaged over the respiratory cycle [18]. Lastly, exercise haemodynamics are most easily performed in the supine position but this does not lead to the same results as erect exercise. In particular, for any workload HR is lower and SV higher in the supine position [22] and the peak workrate achievable higher when erect [28].

There is a role for exercise haemodynamics in established $\mathrm{PH}$. It has provided insights into the physiological behaviour of the pulmonary circulation during exercise in these patients [29]. It can provide diagnostic information to differentiate between clinical classes of PH. Borlaug et al. [30] demonstrated that patients with pulmonary venous hypertension showed a marked increase in PAOP during exercise which could be used to discriminate between this condition and PAH. There is some, albeit limited, evidence for the prognostic value of exercise haemodynamics. Provencher et al. [25] showed that exercise haemodynamic variables could predict change in 6MWD on therapy whereas resting values did not. In a mixed population of subjects with PAH and chronic thromboembolic pulmonary hypertension, Blumberg et al. [31] showed that exercise cardiac index and the pressure/flow relationship were significant prognostic indicators. They may have greater sensitivity than resting values to detect treatment effect. Castelain et al. [29] demonstrated that pressure-flow slopes improved with epoprostenol whereas resting haemodynamic values did not. 
Figure 2. Right heart catheterisation traces of pulmonary artery pressure (PAP) and pulmonary artery occlusion pressure (PAOP) at rest and at peak exercise. Note both the significant elevation of PAP and the marked respiratory swing, most prominently affecting PAOP, which develops on exercise.

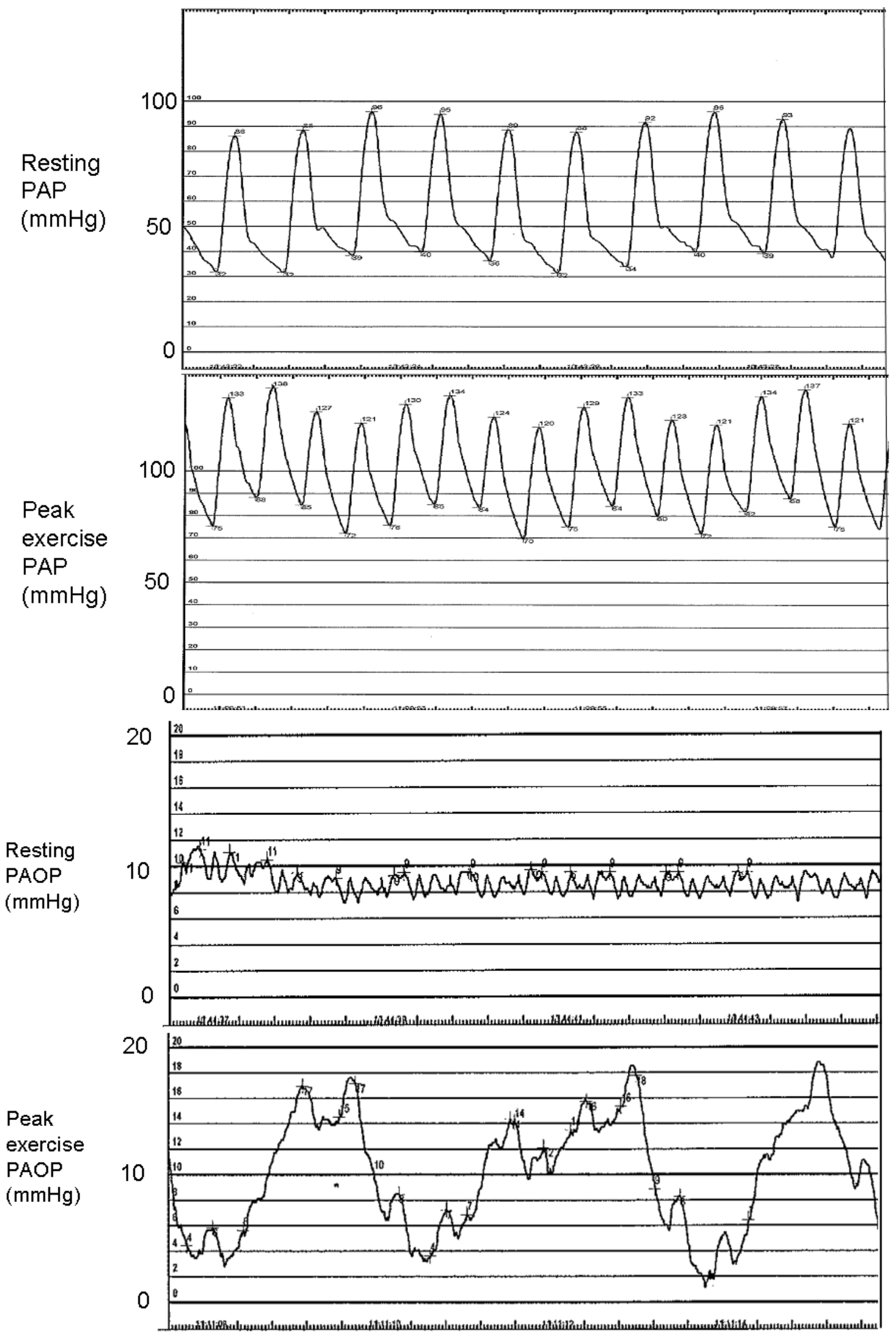


There may be a role for exercise haemodynamics in evaluating subjects with dyspnoea or fatigue that is defying diagnosis particularly if combined with $\mathrm{VO}_{2}$ measurements. In subjects with normal resting measurements, elevated pulmonary artery pressure on exercise has been associated, not only with an impaired exercise capacity and $\mathrm{CO}$ response and higher values of PVR, but also with symptoms, reduced peak $\mathrm{VO}_{2}$, abnormal gas exchange and reduced quality of life [32-34]. Such results support exercise induced PAH (EIPAH) as a true pathophysiological entity which may be responsible for some cases of unexplained exercise intolerance. Since the concept of EIPAH was discouraged in the guidelines from Dana Point (2008) [35] and this advice was repeated in Nice (2013) [36], there has been neither consensus as to whether this is a true precursor of resting PAH nor a widely accepted haemodynamic definition by which to identify it. In a recent review, Naeije et al. [20] have proposed that either an mPAP of $30 \mathrm{mmHg}$ at a $\mathrm{CO}$ of less than $10 \mathrm{~L} \cdot \mathrm{min}^{-1}$ (which approximately corresponds to a PVR greater than 3 Wood units) or a slope of mPAP-CO greater than $3 \mathrm{mmHg} \cdot \mathrm{min} . \mathrm{L}^{-1}$ could be used as diagnostic criteria for this condition.

Exercise haemodynamics may also have a role in identifying EIPAH in subjects with substantial risk factors for PAH as early data suggest treatment may be indicated for this group. One fifth of patients with systemic sclerosis and EIPAH developed resting PAH after a mean follow up of 2.3 years [37]. Exercise haemodynamic measurements in scleroderma patients with borderline resting measurements [38,39] show a greater increase in mPAP on exercise. In this group there was progression in mPAP and PVR on serial measurements over a year and bosentan appeared to attenuate that change [40]. Finally Saggar et al. [41] showed an improvement in exercise haemodynamics in an open label trial of ambrisentan in patients with scleroderma and EIPAH.

\subsection{Non-Invasive Measurements}

For greater utilisation of exercise haemodynamics to occur, the technique for measuring them should be non-invasive and there are a number of candidates for this.

Transthoracic echocardiogram (TTE) surpasses RHC in the amount of information it supplies [42]. Not only can it give estimates of pressure and flow but it can also be used to evaluate right ventricular function. Its major problem, as with all indirect techniques, is the potential for error in patients with challenging anatomy (e.g., concomitant lung disease, obesity) or arising from inter-operator variability.

There are a number of studies illustrating the feasibility of TTE during exercise in PAH and other conditions. These have shown the ability to estimate systolic pulmonary artery pressure (sPAP) [43-48], PAOP by inference from E/e' ratio [49,50], CO from left ventricular outflow velocity-time integral $[43,44]$, resistance $[43,44]$, distensibility $[43,44,51]$ and right ventricular function assessed by tricuspid annular plane systolic excursion (TAPSE) and tricuspid annular systolic velocity [52]. mPAP can be deduced from sPAP using one of the equations derived for this relationship [53,54]. Formal validation of non-invasive with invasive measurements during exercise has been limited [55-57].

Early data show encouraging results for the use of exercise TTE in subjects at risk of PAH. Grunig et al. [58] looked at relatives of patients with IPAH or familial PAH with and without bone morphogenetic protein receptor 2 gene mutations and found a greater prevalence of a hypertensive tricuspid regurgitant velocity response in affected kindreds. Multiple studies have shown a high prevalence of TTE determined EIPAH in scleroderma patients [45,59-63]. Of these, Steen et al. [61] 
was the only one to proceed to RHC in those subjects with EIPAH and confirmed the non-invasive results in $81 \%$ of cases.

Cardiac magnetic resonance (CMR) is a more complex imaging technique which also has potential to provide noninvasive haemodynamic data. It is more accurate than TTE in measuring CO [64] and similarly provides information on right ventricular function, resting values of which have been shown to be superior to PVR for predicting prognosis [65]. However, unlike TTE it cannot provide information on pressure and a significant minority of subjects fail to tolerate the test because of claustrophobia [66]. Additionally exercise measurements so far in PAH have been taken in the immediate post-exercise phase because of the difficulty in cycling whilst inside the bore of the scanner [67]. The validity of this is questionable as values of pressure and flow post-exercise fall rapidly $[44,68]$. This technique needs to be evaluated with imaging performed during exercise to assess its full value. The feasibility of such measurements has been illustrated in other conditions [64].

Simpler physiological measurements have also been used to estimate exercise haemodynamic variables. The inert gas rebreathing technique utilises the high solubility in blood of gases such as acetylene or nitrous oxide to estimate pulmonary blood flow [69]. This technique gives no information on pulmonary artery pressure or other aspects of right ventricular function. It is simple to perform during exercise with a measurement possible every few minutes allowing for a washout period. Its major limitation is in patients with lung disease where ventilation heterogeneity leads to poor mixing of inspired gases and inaccurate results [70]. It is also compromised where there is significant intracardiac shunting.

Nevertheless, the feasibility of the technique to estimate SV during exercise in PAH and detect the effects of disease targeted therapy on exercise SV, have both been demonstrated [67,71]. Lee et al. [71] also showed that, if SV is the variable of interest, then changes in supine resting SV provided as much information as erect exercise values, indicating the importance of preload as a stressor for assessing the pulmonary circulation. Validation data for use of the technique in PAH are limited to resting data [70,72].

Impedance cardiography or bioimpedance uses the change in thoracic impedance as the fluid content of the chest varies during the cardiac cycle to estimate SV [73]. This technique is attractive as it has the potential to provide a continuous measurement of $\mathrm{CO}$ at rest or during activity. However, measurements are not possible in a quarter of patients and the quantitative validity of the data in the remaining proportion cannot be relied upon. Relative changes in measurements of cardiac index were able to identify subjects severely affected by PAH [74]. Bioreactance is a version of the technique which looks at phase rather than amplitude changes of alternating current and voltage applied across the thorax. Its signal is proportional to aortic blood flow and performed well in quantitative terms when validated against thermodilution and indirect Fick in a broad population of PH patients [75].

\section{Cardiopulmonary Exercise Testing}

Improvement in equipment design and widespread adoption of breath by breath measurement techniques have made CPET relatively easy to perform and widely available [76]. The minimum dataset collected during exercise includes $\mathrm{V}_{\mathrm{E}}$, oxygen and carbon dioxide content of inspired and expired air, $\mathrm{HR}$ and oxygen saturation $\left(\mathrm{S}_{\mathrm{p}} \mathrm{O}_{2}\right)$. With these measurements the characteristic pathophysiological response of $\mathrm{PAH}$ patients can be seen, i.e., profound exercise limitation marked by 
impairment of oxygen transport and inefficient gas exchange with very high ventilatory demand [77-85]. In an incremental CPET, the oxygen transport abnormality is reflected in a low $\mathrm{VO}_{2}$ at anaerobic threshold, low $\mathrm{VO}_{2}$ - workrate slope, low peak oxygen $\left(\mathrm{O}_{2}\right)$ pulse (defined as the ratio of peak $\mathrm{VO}_{2}$ to peak HR) and a steep $\mathrm{HR}-\mathrm{VO}_{2}$ response, combined on occasions with a $\mathrm{HR}$ response which fails to reach predicted maximum. The gas exchange response is even more striking with high ventilatory equivalents $\left(\mathrm{V}_{\mathrm{E}} / \mathrm{VCO}_{2}\right.$ and $\left.\mathrm{V}_{\mathrm{E}} / \mathrm{VO}_{2}\right)$ and low end-tidal carbon dioxide $\left(\mathrm{P}_{\mathrm{et}} \mathrm{CO}_{2}\right)$ combined with desaturation (see Figure 3). These features can be exaggerated by the use of walking rather than cycling exercise which causes more hypoxaemia [86] and are more prominent in the presence of a right to left shunt such as through a patent foramen ovale [87].

The exercise response of disease are more subtle. Table 1 lists a number of studies which have examined this issue. Although PAH patients is very readily distinguished from normal subjects. However, differences in CPET results between PAH and other conditions complicated by PH such as left heart problems, hypoxic lung disease and chronic thromboembolic group mean measurements can differentiate between these conditions, using CPET results to make a definitive diagnosis for an individual is not often possible because of the overlap in the range of the abnormal variables. Thus CPET can suggest the presence of $\mathrm{PH}$ in an associated condition but is insufficient without other investigations to make a diagnosis of PAH. One study [88] has proposed an algorithm for diagnosing a pulmonary vascular problem which uses a decision tree based upon peak $\mathrm{VO}_{2}, \mathrm{VO}_{2}$ at anaerobic threshold (AT), breathing reserve and $\mathrm{V}_{\mathrm{E}} / \mathrm{VCO}_{2}$ at AT. This achieved a sensitivity of $79 \%$, specificity of $88 \%$ and accuracy of $85 \%$ of detecting a "pulmonary vascular limit" as the cause of exercise impairment. One major issue with this study was that the definition of "pulmonary vascular limit" used in the study was not a standard one and so these results need further confirmation.

Several CPET variables have been demonstrated to have prognostic value for patients with PAH although some of the studies are limited by small numbers and lack of multivariate analyses [89,90]. Themes emerging from the heterogeneous results are summarised in Table 2. Of note both oxygen transport (peak $\mathrm{VO}_{2}, \mathrm{O}_{2}$ pulse, peak $\mathrm{HR}$ ) and gas exchange variables $\left(\mathrm{V}_{\mathrm{E}} / \mathrm{VCO}_{2}\right.$ at $\left.\mathrm{AT}\right)$ are represented in the table. A further study looked at prognostic information contained in change in variables following treatment with change in peak $\mathrm{VO}_{2}$ being predictive on multivariate analysis [91]. Only one study looked at "Time To Clinical Worsening" [92] as the prognostic outcome rather than death and this showed that peak $\mathrm{VO}_{2}$ was predictive.

CPET variables in some but not all studies have been able to detect a change pre and post approved disease targeted therapy in patients treated for PAH. In an uncontrolled study in 16 subjects Wax et al. [93] showed an improvement in peak $\mathrm{VO}_{2}$ on intravenous prostacyclin therapy. In an uncontrolled study in 11 subjects [94] Wensel et al. was able to show an increase in peak $\mathrm{VO}_{2}$ and reduction in $\mathrm{V}_{\mathrm{E}} / \mathrm{VCO}_{2}$ slope with nebulised iloprost. In a controlled study of 28 subjects [95] Oudiz et al was able to show changes at AT in $\mathrm{V}_{\mathrm{E}} / \mathrm{VCO}_{2}$ ratio and $\mathrm{P}_{\mathrm{et}} \mathrm{CO}_{2}$ with sildenafil. The largest treatment study utilising a CPET variable as a primary outcome measure [14] looked at the use of sitaxentan in 178 subjects. This failed to show an increase in the primary outcome measure $\left(\%\right.$ predicted peak $\left.\mathrm{VO}_{2}\right)$ despite a positive exercise based secondary outcome measure (6MWD) which eventually lead to the drug's approval. The reason for the failure of $\mathrm{VO}_{2}$ as an outcome measure has been attributed to the complexity of CPET and the multicentre design of STRIDE-1 [15]. It has been postulated that this lead to inaccurate results at the less experienced sites and failure of the outcome measure to show a signal. As support for this a single 
centre study in PAH subjects [96] achieved excellent reproducibility of CPET variables on repeated testing with coefficients of variation of 5.8\%, 3.3\%. 5.2\% 6.5\%, 1.0\%, 2.8\% and 3.3\% respectively for peak values of $\mathrm{VO}_{2}, \mathrm{HR}$ and $\mathrm{O}_{2}$ pulse and $\mathrm{AT}$ values of $\mathrm{VO}_{2}, \mathrm{P}_{\mathrm{et}} \mathrm{O}_{2}, \mathrm{P}_{\mathrm{et}} \mathrm{CO}_{2}$ and $\mathrm{V}_{\mathrm{E}} / \mathrm{VCO}_{2}$.

Figure 3. Typical CPET responses of a patient with PAH. The solid lines in (A), (B) and (C) indicate the predicted peak values of the respective variables. The dashed line in (A) represents a $\mathrm{VO}_{2} / \mathrm{WR}$ slope of $10 \mathrm{~mL}$.W./ $\mathrm{min}^{-1}$ - a healthy response would parallel this line. Note the shallower $\mathrm{VO}_{2} / \mathrm{WR}$ slope and reduced peak $\mathrm{VO}_{2}$ in $\mathrm{PAH}$. Reduced peak oxygen pulse is seen in (B). Steep heart rate response and $\mathrm{V}_{\mathrm{E}} / \mathrm{VCO}_{2}$ slope are evident in (C) and (D) respectively with the predicted response corridors indicated by dashed lines. (E) displays a markedly elevated ventilatory equivalent of $\mathrm{CO}_{2}$ while (F) shows reduced end-tidal $\mathrm{CO}_{2}$, demonstrating key elements of the abnormal gas exchange response in PAH.
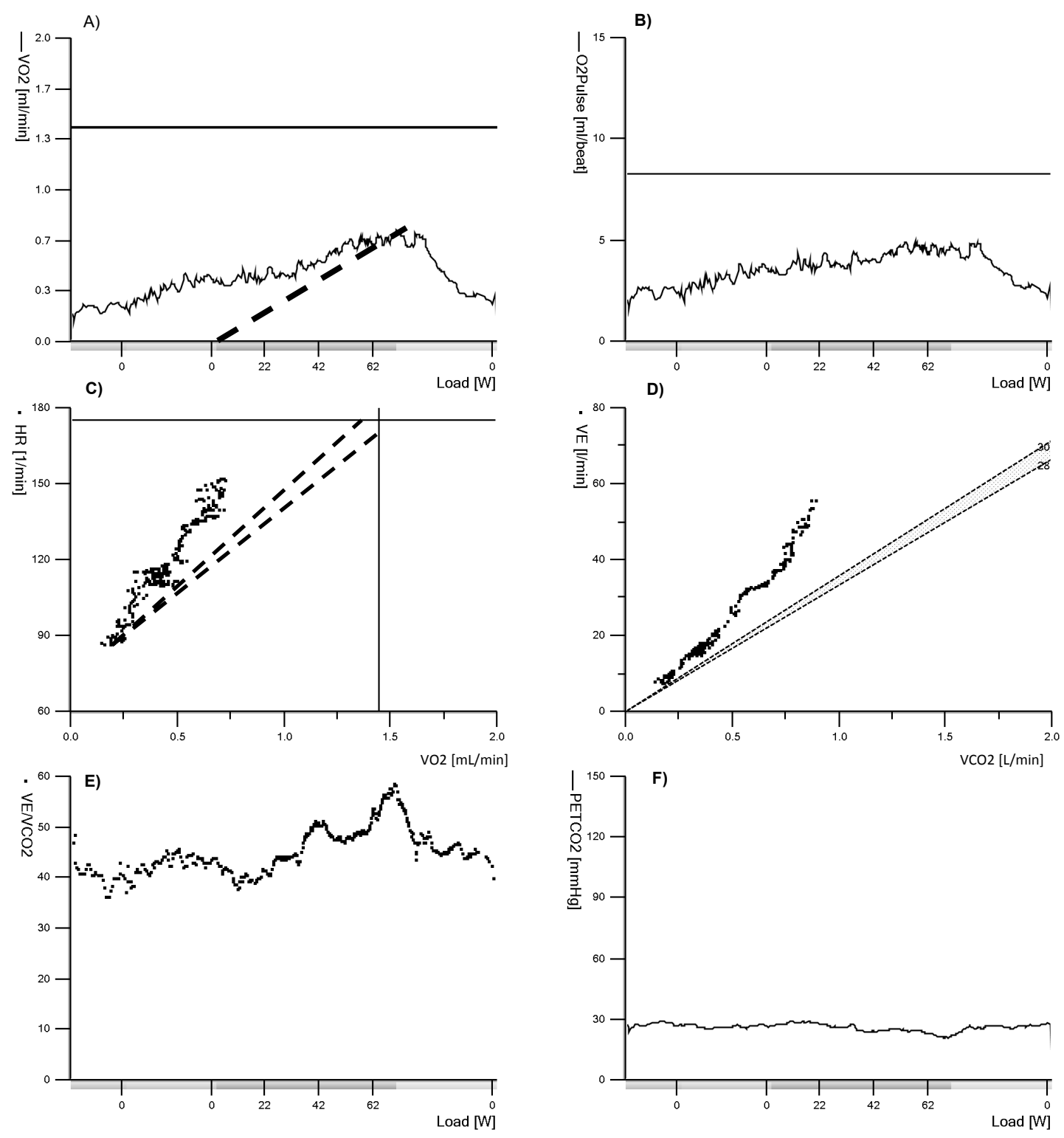

Screening of at risk populations for the presence of resting PH is best performed by TTE. However, if it becomes important to detect EIPAH, then this may be an appropriate indication for CPET. Studies 
which examined CPET variable abnormalities in EIPAH are listed in Table 3. The ability of CPET to detect these differences adds support to the concept of EIPAH as a genuine pathophysiological entity.

The safety of maximal incremental CPET in PAH subjects has been questioned. Multiple studies in adults $[83,96,97]$ and children $[89,98,99]$ have suggested that this is not a problem. In the largest study looking at CPET in high risk cardiovascular patients ( $\mathrm{n}=5060$ CPET events) [97], adverse event rate was $0.16 \%$ with no fatalities. In a study dedicated to PAH [96], there were no events in 242 tests.

Table 1. Studies comparing cardiopulmonary exercise test (CPET) variable responses in PAH with left heart, hypoxic lung and chronic thromboembolic disease or in these conditions complicated by $\mathrm{PH}$.

\begin{tabular}{|c|c|c|}
\hline$\underline{\text { Study }}$ & Population & Finding \\
\hline \multicolumn{3}{|l|}{ Left Heart Disease } \\
\hline Deboeck 2004 [100] & LHD (19), PAH (19) & $\begin{array}{l}\text { Matched for peak } \mathrm{VO}_{2}, \text { PAH patients have } \\
\text { - higher dyspnoea scores } \\
\text { - } \text { higher } \mathrm{V}_{\mathrm{E}} / \mathrm{VCO}_{2} \text { at } \mathrm{AT} \text { and peak } \\
\text { - lower peak } \mathrm{O}_{2} \text { pulse } \\
\text { - lower peak } \mathrm{S}_{\mathrm{p}} \mathrm{O}_{2} \\
\text { - } \\
\text { lower } \mathrm{VO}_{2}-\mathrm{WR} \text { slope above AT }\end{array}$ \\
\hline Hansen 2007 [101] & $\begin{array}{l}\text { Normal (25), COPD (25), } \\
\text { LHD (25), IPAH (25) }\end{array}$ & $\begin{array}{l}\text { Matched for peak } \mathrm{VO}_{2} \text {, lower peak } \\
\mathrm{P}_{\mathrm{et}} \mathrm{CO}_{2} \text { in } \mathrm{PAH}\end{array}$ \\
\hline Groepenhoff 2010 [102] & PAH ( 28), LHD (18) & 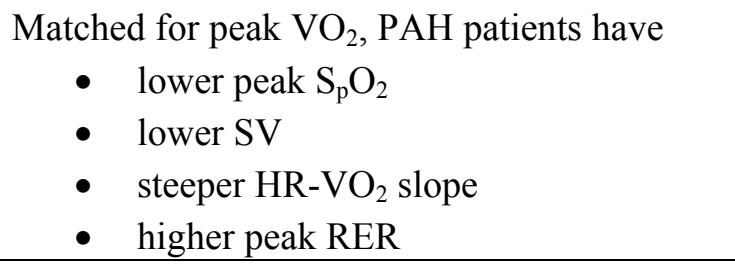 \\
\hline Nishio 2012 [103] & LHD (20), PAH (20) & $\begin{array}{l}\text { Matched for NYHA FC, peak } \mathrm{VO}_{2} \text { lower and } \\
\mathrm{V}_{\mathrm{E}} / \mathrm{VCO}_{2} \text { slope higher in PAH. Peak } \mathrm{VO}_{2} \\
\text { correlated with PVR in PAH and PAOP in } \\
\text { LHD. } \mathrm{V}_{\mathrm{E}} / \mathrm{VCO}_{2} \text { slope correlated with PAOP } \\
\text { in LHD }\end{array}$ \\
\hline Guazzi 2013 [104] & $\begin{array}{l}\text { LHD (293); (134 had PH } \\
\text { on TTE) }\end{array}$ & $\begin{array}{l}\text { Presence of } \mathrm{PH} \text { associated with high } \mathrm{V}_{\mathrm{E}} / \mathrm{VCO}_{2} \\
\text { slope, low peak } \mathrm{P}_{\mathrm{et}} \mathrm{CO}_{2} \text { and presence of } \\
\text { oscillatory breathing }\end{array}$ \\
\hline \multicolumn{3}{|l|}{ COPD } \\
\hline Hansen 2007 [101] & $\begin{array}{l}\text { Normal (25), COPD (25), } \\
\text { LHD (25), IPAH (25) }\end{array}$ & $\begin{array}{l}\text { Matched for peak } \mathrm{VO}_{2} \text {, } \mathrm{PAH} \text { patients have } \\
\text { lower peak } \mathrm{P}_{\mathrm{et}} \mathrm{CO}_{2} \text {, higher peak } \mathrm{P}_{\mathrm{e}} \mathrm{CO}_{2} \text { and } \\
\text { higher peak } \mathrm{P}_{\mathrm{e}} \mathrm{CO}_{2} / \mathrm{P}_{\mathrm{et}} \mathrm{CO}_{2} \text { ratio }\end{array}$ \\
\hline Vonbank 2008 [105] & $\begin{array}{l}\text { COPD (42); PH } \\
\text { determined by RHC } \\
\text { present in } 32\end{array}$ & $\begin{array}{l}\text { Not matched for peak } \mathrm{VO}_{2}(\text { lower in } \mathrm{PH}) \text {. } \\
\text { Presence of } \mathrm{PH} \text { during exercise associated } \\
\text { with } \\
\text { - high } \mathrm{VO}_{2}-\mathrm{WR} \text { slope } \\
\text { - high } \mathrm{V}_{\mathrm{E}} / \mathrm{VCO}_{2} \\
\text { - } \\
\text { high } \mathrm{P}_{(\mathrm{a}-\mathrm{et})} \mathrm{CO}_{2}\end{array}$ \\
\hline
\end{tabular}


Table 1. Cont.

\begin{tabular}{|c|c|c|}
\hline$\underline{\text { Study }}$ & Population & Finding \\
\hline Boerrigter 2012 [106] & $\begin{array}{l}\text { COPD (47); (stratified for } \\
\text { severity of PH determined at } \\
\text { RHC - no PH (24), mPAP } \\
25-39 \mathrm{mmHg}(14), \text { mPAP } \geq \\
40 \mathrm{mmHg}(9)\end{array}$ & $\begin{array}{l}\text { As } \mathrm{PH} \text { severity increased, } \\
\text { - } \quad \text { reduced peak } \mathrm{S}_{\mathrm{v}} \mathrm{O}_{2} \\
\text { - } \quad \text { reduced peak } \mathrm{P}_{\mathrm{a}} \mathrm{CO}_{2} \\
\text { - } \quad \text { reduced peak } \mathrm{S}_{\mathrm{p}} \mathrm{O}_{2} \\
\text { - } \quad \text { increased breathing reserve } \\
\text { - } \quad \text { increased peak } \mathrm{RER} \\
\text { - } \quad \text { reduced peak } \mathrm{P}_{\mathrm{et}} \mathrm{CO}_{2} \\
\text { - increased } \mathrm{V}_{\mathrm{E}} / \mathrm{VCO}_{2} \text { slope } \\
\text { - switch from ventilatory to cardiovascular } \\
\text { limitation profile }\end{array}$ \\
\hline \multicolumn{3}{|r|}{ e } \\
\hline Glaser 2009 [107] & $\begin{array}{l}\text { IPF (34); PH determined by } \\
\text { TTE and confirmed by RHC } \\
\text { in } 16\end{array}$ & $\begin{array}{l}\text { Not matched for peak } \mathrm{VO}_{2}(\text { lower in } \mathrm{PH}) \text {. } \\
\text { Presence of } \mathrm{PH} \text { associated with } \\
\text { - } \text { higher dyspnoea scores } \\
\text { - } \text { higher } \mathrm{V}_{\mathrm{E}} / \mathrm{VCO}_{2} \text { slope } \\
\text { - } \text { higherP }_{(\mathrm{a}-\mathrm{ET})} \mathrm{CO} 2 \text { at } \mathrm{AT}\end{array}$ \\
\hline van der Plas 2013 [108] & $\begin{array}{l}\text { IPF }(38) ; \mathrm{mPAP} \geq 40 \mathrm{mmHg} \\
\text { on TTE in } 11\end{array}$ & $\begin{array}{l}\mathrm{V}_{\mathrm{E}} / \mathrm{VCO}_{2} \text { at } \mathrm{AT} \text { higher in group with } \\
\mathrm{mPAP} \geq 40 \mathrm{mmHg}\end{array}$ \\
\hline \multicolumn{3}{|l|}{ СТЕРН } \\
\hline Zhai 2011 [9] & РАН (77), СТЕРН (50) & 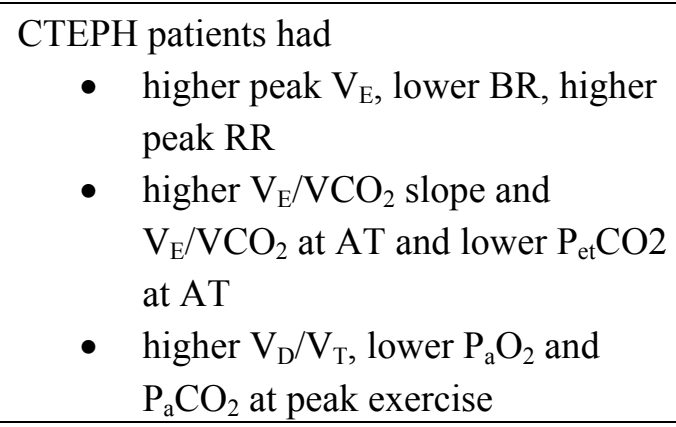 \\
\hline McCabe 2013 [109] & CTEPH (15), CTED (15) & $\begin{array}{l}\text { Not matched for peak } \mathrm{VO}_{2} \text {. } \\
\text { CTEPH patients had } \\
\text { - } \text { higher } \mathrm{V}_{\mathrm{E}} / \mathrm{VCO}_{2} \text { slope and } \\
\mathrm{V}_{\mathrm{E}} / \mathrm{VCO}_{2} \text { at } \mathrm{AT} \text { and lower } \mathrm{P}_{\mathrm{et}} \mathrm{CO}_{2} \\
\text { at } \mathrm{AT} \\
\text { - } \\
\text { higher } \mathrm{V}_{\mathrm{D}} / \mathrm{V}_{\mathrm{T}} \text {, Aa gradient, lower } \\
\mathrm{P}_{\mathrm{a}} \mathrm{O}_{2} \text { at peak exercise }\end{array}$ \\
\hline
\end{tabular}

CPET: cardiopulmonary exercise test; PAH: pulmonary arterial hypertension; PH: pulmonary hypertension; LHD: left heart disease; COPD: chronic obstructive pulmonary disease; IPAH: idiopathic pulmonary arterial hypertension; RHC: right heart catheterisation; TTE: transthoracic echocardiogram; MPAP: mean pulmonary artery pressure; IPF: idiopathic pulmonary fibrosis; CTEPH: chronic thromboembolic pulmonary hypertension; CTED: chronic thromboembolic disease; $\mathrm{VO}_{2}$ : oxygen uptake; $\mathrm{V}_{\mathrm{E}}$ : ventilation; $\mathrm{VCO}_{2}$ : carbon dioxide production; $\mathrm{O}_{2}$ pulse: oxygen pulse; $\mathrm{S}_{\mathrm{p}} \mathrm{O}_{2}$ : oxygen saturation; WR: workrate; $\mathrm{P}_{\mathrm{et}} \mathrm{CO}_{2}$ : end-tidal carbon dioxide; SV: stroke volume; HR: heart rate; RER: respiratory exchange ratio; NYHA FC: New York Heart Association functional class; PAOP: pulmonary artery occlusion pressure; $\mathrm{P}_{\mathrm{e}} \mathrm{CO}_{2}$ : mixed-expired carbon dioxide; $\mathrm{P}_{(\mathrm{a}-\mathrm{et})} \mathrm{CO}_{2}$ : arterial to end-tidal carbon dioxide pressure difference; $\mathrm{S}_{\mathrm{v}} \mathrm{O}_{2}$ : mixed venous oxygen saturation; $\mathrm{P}_{\mathrm{a}} \mathrm{CO}_{2}$ : arterial partial pressure of carbon dioxide; Aa gradient: Alveolar-arterial gradient; $\mathrm{P}_{\mathrm{a}} \mathrm{O}_{2}$ : arterial partial pressure of oxygen. 
Table 2. Studies of prognostic value of CPET variables in PAH subjected to multivariate analysis.

\begin{tabular}{ll}
\hline Significant CPET Variables & Studies \\
\hline Peak $\mathrm{VO}_{2}$ & Wensel 2002 (absolute value) [110], Wensel \\
Peak systolic BP & 2013 (\% predicted) [111] \\
$\mathrm{V}_{\mathrm{E}} / \mathrm{VCO}_{2}$ at AT & Wensel 2002 [110] \\
$\Delta \mathrm{O}_{2}$ pulse & Oudiz 2010 [112], Deboeck 2012 [92] \\
Peak HR / $\Delta \mathrm{HR}$ & Groepenhoff 2008 [113] \\
Change in peak $\mathrm{VO}_{2}$ with treatment & Groepenhoff 2013 [91] / Wensel 2013 [111] \\
Presence of right to left shunt & Oudiz 2010 [112] \\
\hline
\end{tabular}

CPET: cardiopulmonary exercise test; PAH: pulmonary arterial hypertension; $\mathrm{VO}_{2}$ : oxygen uptake; BP: blood pressure; $\mathrm{V}_{\mathrm{E}}$ : ventilation; $\mathrm{VCO}_{2}$ : carbon dioxide production; AT: anaerobic threshold; $\Delta \mathrm{O}_{2}$ pulse: increase in oxygen pulse during exercise; HR: heart rate; $\triangle \mathrm{HR}$ : increase in HR during exercise.

Table 3. Studies showing CPET variable abnormalities in exercise induced PAH (EIPAH).

\begin{tabular}{|c|c|c|}
\hline Study & Population & Finding in EIPAH \\
\hline Tolle 2008 [34] & $\begin{array}{l}\text { Unexplained dyspnoea and } \\
\text { fatigue with EIPAH }(n=78)\end{array}$ & $\begin{array}{l}\text { Reduced peak } \mathrm{VO}_{2} \text {, increased peak Aa } \\
\text { gradient }\end{array}$ \\
\hline Dumitrescu 2010 [114] & Scleroderma $(n=30)$ & $\begin{array}{l}\text { Lower } \mathrm{VO}_{2} \text { at peak and } \mathrm{AT} \text {, lower peak } \mathrm{O}_{2} \\
\text { pulse; lower } \mathrm{VO}_{2}-\mathrm{WR} \text { slope, higher } \\
\mathrm{V}_{\mathrm{E}} / \mathrm{VCO}_{2} \text { and lower } \mathrm{P}_{\mathrm{et}} \mathrm{CO}_{2} \text { at AT }\end{array}$ \\
\hline Fowler 2011 [33] & $\begin{array}{l}\text { Dyspnoea in scleroderma, family } \\
\text { history of PAH, borderline PH } \\
\text { (sPAP } 35-45 \mathrm{mmHg} \text { on resting } \\
\text { TTE) }(\mathrm{n}=57)\end{array}$ & Elevated $\mathrm{V}_{\mathrm{E}} / \mathrm{VCO}_{2}$ and reduced $\mathrm{P}_{\mathrm{et}} \mathrm{CO}_{2}$ at $\mathrm{AT}$ \\
\hline Schwaiblmair 2012 [115] & $\begin{array}{l}\text { Borderline PH (mPAP 21-24 } \\
\text { mmHg on RHC) }(n=53)\end{array}$ & $\begin{array}{l}\text { Reduced peak } \mathrm{VO}_{2} \text {, increased } \mathrm{V}_{\mathrm{E}} / \mathrm{VO}_{2} \text { at } \\
\text { AT, increased } \mathrm{V}_{\mathrm{D}} / \mathrm{V}_{\mathrm{T}} \text {, increased Aa } \\
\text { gradient, increased } \mathrm{P}_{(\mathrm{a}-\mathrm{et})} \mathrm{CO}_{2}\end{array}$ \\
\hline
\end{tabular}

CPET: cardiopulmonary exercise test; EIPAH: exercise induced pulmonary arterial hypertension; PAH: pulmonary arterial hypertension; PH: pulmonary hypertension; SPAP: systolic pulmonary arterial pressure; TTE: transthoracic echocardiogram; mPAP: mean pulmonary arterial hypertension; RHC: right heart catheterisation; $\mathrm{VO}_{2}$ : oxygen uptake; Aa gradient: alveolar-arterial pressure gradient; AT: anaerobic threshold; $\mathrm{O}_{2}$ pulse: oxygen pulse; WR: workrate; $\mathrm{V}_{\mathrm{E}}$ : ventilation; $\mathrm{VCO}_{2}$ : carbon dioxide production; $\mathrm{P}_{\mathrm{et}} \mathrm{CO}_{2}$ : end-tidal partial pressure of carbon dioxide; $\mathrm{V}_{\mathrm{D}} / \mathrm{V}_{\mathrm{T}}$ : ratio of dead space volume to tidal volume, $\mathrm{P}_{(\mathrm{a}-\mathrm{et})} \mathrm{CO}_{2}$ : arterial to end-tidal carbon dioxide pressure difference.

In summary, studies of CPET in PAH have been encouraging but not unconditionally so. The test can discriminate readily between subjects with PAH and normals but overlap of CPET variable responses between PAH and other comorbidities such as heart and lung disease can reduce its usefulness as a discriminator between differential diagnoses. Several of the CPET variables have prognostic value but studies have had heterogeneous results and they are not as strongly predictive as simpler variables (6MWD). CPET variables can detect treatment effect but larger studies were perhaps compromised by the complexity of the test. Finally CPET variables can detect abnormalities present in 
EIPAH but this condition is of uncertain clinical significance.

Several approaches for enhancing the utility of CPET in PAH have been proposed. One suggestion has been to use submaximal rather than maximal testing [71,116-118]. This simplifies the test, removing the subjective element of maximal effort, making it shorter and potentially more reliable to administer, and may not lose any of the responsiveness. Whilst most studies have concentrated solely on measurement of gas exchange variables in this context $\left(\mathrm{P}_{\mathrm{et}} \mathrm{CO}_{2}, \mathrm{~V}_{\mathrm{E}} / \mathrm{VCO}_{2}\right)$, Lee et al. [44] looked at isotime measurement of the complete array of CPET variables after three minutes of low level steady state exercise. They found that whereas both oxygen transport $\left(\mathrm{VO}_{2}, \mathrm{O}_{2}\right.$ pulse $)$ and gas exchange variables $\left(\mathrm{V}_{\mathrm{E}} / \mathrm{VCO}_{2}\right.$ at $\left.\mathrm{AT}\right)$ distinguished between different severity of $\mathrm{PAH}$, only the former showed change pre and post treatment.

Another approach has been to introduce new CPET variables often based upon pattern of variable response rather than peak values [119]. Oxygen uptake kinetics are slower in these patients and represent one potential avenue which could be explored via time constants or post-exercise $\mathrm{VO}_{2}$ decline. Autonomic imbalance with increased sympathetic and reduced parasympathetic activity can be present leading to delay in heart rate recovery (HRR). The latter was shown to be reduced in PAH [2] and had prognostic significance on multivariate analysis when only CPET variables were considered [120]. Oxygen uptake efficiency slope (OUES) [121] which represents the slope of a plot of $\mathrm{VO}_{2}$ against $\log$ $\mathrm{V}_{\mathrm{E}}$ is thought to encapsulate in one variable a measure of oxygen transport and gas exchange. It can be used as an estimate of peak $\mathrm{VO}_{2}$ which requires only submaximal effort [121,122]. It has recently been shown to be of prognostic value in PAH [123].

\section{Field Exercise Tests}

The application of field exercise tests in subjects with PAH has been overwhelmingly dominated by the 6MWT which has as outcome measurement 6MWD. As its name implies, this is a fixed time walking test whose major requirement is a quiet $30 \mathrm{~m}$ corridor. There is detailed guidance on how the test should be performed [124] and its reproducibility and validation are well documented. Deboeck et al. [125] demonstrated the physiological response to the test in PAH subjects to be a submaximal test performed using predominantly aerobic metabolism. In common with other conditions [126], the 6MWD in PAH correlates with both the peak $\mathrm{VO}_{2}$ achievable and the $\mathrm{VO}_{2}$ attained during the test [125,127]. The product of $6 \mathrm{MWD}$ and weight improves the correlation $[15,125,128]$. 6MWD correlates with resting haemodynamics including $\mathrm{CO}$ and total pulmonary resistance but not mPAP [127]. It also correlates with New York Heart Association Functional Class [127] and quality of life [129]. Similarly change in six minute walk distance $(\triangle 6 \mathrm{MWD})$ following $\mathrm{PAH}$ treatment correlated with changes in cardiac index, PVR [130] and quality of life [129].

The short, fixed duration of administration makes it highly convenient for routine clinical use. Unfortunately it also has significant drawbacks. It can be surprisingly difficult to locate a $30 \mathrm{~m}$ corridor sufficiently quiet for regular use. Comorbidity with the pulmonary vascular axis which is particularly relevant in associated forms of $\mathrm{PAH}$, such as scleroderma, compromise the reliability of the results $[131,132]$. The test has a ceiling effect as the linear relationship between peak $\mathrm{VO}_{2}$ and 6MWD is lost in less impaired subjects [71,133-136]. This makes it more responsive to change in more severely affected individuals and vice versa in fitter individuals. Additionally there is a learning 
effect [137] of approximately 2 to $4 \%$ between three consecutive daily walks, seen both at baseline and at two months follow up in healthy individuals. There was, however, no learning effect seen between two walks performed two months apart.

The major strength of the 6MWT is the ability of a baseline measurement to predict prognosis in IPAH which has resulted in its inclusion in several $\mathrm{PH}$ registry models for predicting survival including the French PH registry [138], the risk calculator derived from REVEAL (the North American database) [139] and the Scottish Composite Score [140]. This was also demonstrable in a meta-analysis of the many treatment trials in PAH [141]. It retains significance in multivariate analyses even when other strong predictors are included such as patient demographics [127,140], baseline haemodynamics from right heart catheterisation or CMR [140,142,143], CPET variables [92,113] and presence of pericardial effusion [127]. Absolute values of 6MWD measured following PAH treatment retain prognostic power but do not improve on the baseline measurement [144]. The prognostic power is reduced and may be lost in cases of associated PAH such as connective tissue disease [37,92].

Changes are seen in 6MWD with PAH treatment and it has been used as a surrogate outcome measure to obtain registration for most of the medications now used in this condition [145,146]. Although $\triangle 6 \mathrm{MWD}$ correlates with change in haemodynamics following PAH treatment [130], it has proven very difficult to demonstrate any prognostic power of $\triangle 6 \mathrm{MWD}$ with therapy despite being sought by several studies and meta-analyses [17,141,142,144,147]. The mechanism of this phenomenon has been explored recently by two further studies. In a meta-analysis of 22 PAH treatment studies, Savarese et al. [130] demonstrated that the change in haemodynamics seen with PAH treatment and correlating with $\triangle 6 \mathrm{MWD}$ did not predict subsequent clinical events. In a pooled analysis of ten PAH treatment studies submitted to the US Food and Drug Administration (2404 patients), Gabler et al. [16] found that, despite a significant improvement in $6 \mathrm{MWD}$, it accounted for only $22.1 \%$ of the treatment effect and they concluded that it was at best a modest surrogate endpoint for clinical events. To explain this anomaly it has been hypothesised that treatment improves both right ventricular function and haemodynamics but that only the former is strongly linked to clinical outcome [65]. Consequently $\triangle 6 \mathrm{MWD}$ which correlates more strongly with change in haemodynamics [130] than change in right ventricular function [148] is poorly linked to clinical outcomes.

Given the poor performance of $\triangle 6 \mathrm{MWD}$ in predicting clinical outcome, it is unknown whether this represents an insurmountable drawback or whether change in implementation of the test can improve its performance. Use of minimal important differences may be of some value here as there will then be confidence that changes in $6 \mathrm{MWD}$, although not prognostic, do have some bearing on the morbidity experienced by the patient. Estimates of this for the 6MWT in PAH subjects have suggested an increase in 6MWD of between 26 and $42 \mathrm{~m}$ to be clinically relevant $[16,149,150]$. Alternatively, absolute rather than predicted values of $6 \mathrm{MWD}$ are commonly used as targets in clinical practice, which may obscure prognostic information as the distance covered by a $2 \mathrm{~m}$ tall 30 year old male will be very different from that expected from a $1.5 \mathrm{~m} 70$ year old female. However, analysis of the relative performance of absolute and \% predicted 6MWD did not show any difference in the ability of the two values to predict prognosis [151].

Measurements of $\mathrm{HR}$ and $\mathrm{S}_{\mathrm{p}} \mathrm{O}_{2}$ routinely made during the 6MWT may confer additional value on the test. It has been shown that, as in left heart disease, patients with PAH have altered autonomic nervous system activity, the degree of which may reflect disease severity [152]. Such abnormalities 
may be visible in heart rate response during recovery from exercise and readily measured in variables such as HRR1, which is the fall in HR during the first minute of recovery. Minai et al. [153] have measured this following a 6MWT in idiopathic PAH and found it to complement the ability of 6MWD to predict clinical worsening. Similarly in an older study with a limited multivariate analysis on a small cohort $(\mathrm{n}=34)$ [154], the size of fall in $\mathrm{S}_{\mathrm{p}} \mathrm{O}_{2}$ during the 6MWT was found to be of prognostic value with a $27 \%$ increase in risk of death over the study period (1992-1997) for each percentage point fall in saturation. The relevance of this in the modern treatment era is uncertain.

Waiting in the wings should the recent fall in fortune of the 6MWT prove irretrievable, there are a number of alternative exercise test candidates vying to displace it from its central position in the clinical management of PAH. Treadmill based walks have been proposed by several authors [155-158]. This is a convenient method of administering an exercise test not requiring a corridor with well-established protocols (such as Naughton-Balke) developed primarily for cardiac stress testing. The physiological stress imposed by such protocols is incremental in nature and avoids the ceiling effect issue seen with the 6MWT. Because of the fixed position of the subject, it can be combined with gas exchange measurements which moves it in complexity towards a formal CPET. $\mathrm{S}_{\mathrm{p}} \mathrm{O}_{2}$ and other gas exchange measurements obtained during cycle and treadmill ergometry testing are not directly comparable because treadmill exercise leads to more desaturation and increased ventilatory inefficiency [86]. Changes in performance on treadmill testing were found to correlate with change in haemodynamics following PAH treatment [155] and treadmill exercise capacity was a predictor of mortality on multivariate analysis [156]. The REVEAL risk equation for PAH contains 6MWD. A study [158] which replaced this with treadmill test performance improved the predictive value of the equation. A treadmill version of the 6MWT has been developed where the speed of the treadmill is increased every $30 \mathrm{~s}$ following patient instructions [157] until a maximum is reached. If indicated by the subject, the speed can be decreased before the end of the test is reached. The outcome of the test is the distance walked on the treadmill in 6 min.

Shuttle walk tests are popular field exercise tests which require only a $10 \mathrm{~m}$ corridor. The incremental shuttle walk test imposes a linear physiological stress avoiding a ceiling effect and has been used by some PH groups $[159,160]$. The walk distance achieved correlates more strongly with peak $\mathrm{VO}_{2}$ than 6MWD [160] but this is unsurprising given that it is an incremental test whereas the $6 \mathrm{MWT}$ is not. Endurance protocols are generally thought to be more sensitive ways of detecting a treatment effect than incremental tests [161]. There is only one study [162] comparing the relative ability of 6MWT, endurance shuttle walk test and constant load cycle ergometry CPET to detect treatment effect in PAH. The results suggest that the 6MWT is the most reproducible and responsive of the three.

Step climbing tests have received some attention in PAH studies. Again this test has a very small footprint and, because of the fixed location of the test, it can be combined with more elaborate gas exchange measurements. Fox et al. [163] found that step test performance was impaired in PAH and was correlated with functional class and 6MWD. Bernstein et al. [164] assessed the use of change in $\mathrm{P}_{\mathrm{et}} \mathrm{CO}_{2}$ measurements during a step test in patients with scleroderma with and without established PAH. They found a correlation with mPAP determined by RHC in a subset of the patients and the measurement performed well as a screening test for $\mathrm{PH}$ in this group.

Activity monitoring is topical in many disease groups as daily activity is possibly a measurement more relevant to the burden of disease experienced by the patient than the performance of an exercise 
test. Both Mainguy et al. [165] and Pugh et al. [166] demonstrated a reduction in daily life physical activities and increased sedentary time in PAH. Preliminary data published by Ulrich et al. [167] have suggested poorer survival in those with reduced daytime activity and Frantz et al. [168] provided evidence that treatment can improve activity levels.

\section{Future of Exercise Testing in PAH}

There are roles for all the modes of exercise testing discussed above in the management of PAH and a summary of what these may be in the future is suggested in Table 4.

Table 4. Likely future Indications for exercise testing modalities in management of PAH.

\begin{tabular}{ccccc}
\hline & $\begin{array}{c}\text { Invasive } \\
\text { Haemodynamics }\end{array}$ & $\begin{array}{c}\text { Non-invasive } \\
\text { haemodynamics }\end{array}$ & $\underline{\text { CPET }}$ & Field tests \\
\hline Screening & - & ++ & ++ & - \\
Diagnosis & ++ & + & + & - \\
Prognosis & + & + & + & ++ \\
Follow-up & - & ++ & + & ++ \\
\hline
\end{tabular}

- little or no role; + some role; ++ major role.

Invasive exercise haemodynamics remains the reference standard for investigating the possible diagnosis of EIPAH and its use in this context will hopefully answer the question of the clinical relevance of this condition. It is also useful as a test of last resort in the investigation of subjects with unexplained dyspnoea or fatigue. It will not have a major role in screening or follow-up of subjects and in that area it is likely that non-invasive methods of determining cardiac haemodynamics will increase their foothold.

CPET is a cumbersome tool to use routinely. Its areas of growth are likely to include screening for subclinical disease and a focussing of the test towards follow up of fitter patients less well served by field tests. It is also likely that there will be increasing use of new variables such as OUES and HRR1 and application of cut-down submaximal tests more convenient for widespread clinical use.

Given the major investment so far in 6MWTs and their acknowledged prognostic power in the more impaired patients, it seems unlikely that they will be replaced by alternative field tests. It is possible that more use will be made of additional variables such as HRR1. The major growth in this area may be in activity monitoring, particularly given the flexibility of this mode of measurement and its link with rehabilitation programmes.

\section{Conclusion}

Exercise testing occupies a major role in the management of PAH. Critical review of its current utilisation shows scope for improvement of its implementation and expansion in the indications (screening, diagnosis, prognosis, monitoring of outcomes) for which it is used. This applies to a wide range of tests from invasive haemodynamics through to activity monitoring over prolonged periods. We predict continued and growing research interest in this modality of assessment of PAH. 


\section{Author Contributions}

MKJ performed the literature review and wrote the article. ST produced the figures and reviewed the text.

\section{Conflicts of Interest}

The authors declare no conflict of interest.

\section{References}

1. Chemla, D.; Castelain, V.; Hoette, S.; Creuze, N.; Provencher, S.; Zhu, K.; Humbert, M.; Herve, P. Strong linear relationship between heart rate and mean pulmonary artery pressure in exercising patients with severe precapillary pulmonary hypertension. Am. J. Physiol. Heart Circ. Physiol. 2013, 305, H769-H777.

2. Dimopoulos, S.; Anastasiou-Nana, M.; Katsaros, F.; Papazachou, O.; Tzanis, G.; Gerovasili, V.; Pozios, H.; Roussos, C.; Nanas, J.; Nanas, S. Impairment of autonomic nervous system activity in patients with pulmonary arterial hypertension: A case control study. J. Card. Fail. 2009, 15, 882-889.

3. Soon, E.; Treacy, C.M.; Toshner, M.R.; MacKenzie-Ross, R.; Manglam, V.; Busbridge, M.; Sinclair-McGarvie, M.; Arnold, J.; Sheares, K.K.; Morrell, N.W.; et al. Unexplained iron deficiency in idiopathic and heritable pulmonary arterial hypertension. Thorax 2011, 66, 326-332.

4. Melot, C.; Naeije, R. Pulmonary vascular diseases. Compr. Physiol. 2011, 1, 593-619.

5. Sun, X.G.; Hansen, J.E.; Oudiz, R.J.; Wasserman, K. Pulmonary function in primary pulmonary hypertension. J. Am. Coll. Cardiol. 2003, 41, 1028-1035.

6. Meyer, F.J.; Ewert, R.; Hoeper, M.M.; Olschewski, H.; Behr, J.; Winkler, J.; Wilkens, H.; Breuer, C.; Kubler, W.; Borst, M.M. Peripheral airway obstruction in primary pulmonary hypertension. Thorax 2002, 57, 473-476.

7. Laveneziana, P.; Garcia, G.; Joureau, B.; Nicolas-Jilwan, F.; Brahimi, T.; Laviolette, L.; Sitbon, O.; Simonneau, G.; Humbert, M.; Similowski, T. Dynamic respiratory mechanics and exertional dyspnoea in pulmonary arterial hypertension. Eur. Respir. J. 2013, 41, 578-587.

8. Richter, M.J.; Voswinckel, R.; Tiede, H.; Schulz, R.; Tanislav, C.; Feustel, A.; Morty, R.E.; Ghofrani, H.A.; Seeger, W.; Reichenberger, F. Dynamic hyperinflation during exercise in patients with precapillary pulmonary hypertension. Resp. Med. 2012, 106, 308-313.

9. Zhai, Z.; Murphy, K.; Tighe, H.; Wang, C.; Wilkins, M.R.; Gibbs, J.S.; Howard, L.S. Differences in ventilatory inefficiency between pulmonary arterial hypertension and chronic thromboembolic pulmonary hypertension. Chest 2011, 140, 1284-1291.

10. de Man, F.S.; Handoko, M.L.; Groepenhoff, H.; van't Hul, A.J.; Abbink, J.; Koppers, R.J.; Grotjohan, H.P.; Twisk, J.W.; Bogaard, H.J.; Boonstra, A.; et al. Effects of exercise training in patients with idiopathic pulmonary arterial hypertension. Eur. Resp. J. 2009, 34, 669-675.

11. Tolle, J.; Waxman, A.; Systrom, D. Impaired systemic oxygen extraction at maximum exercise in pulmonary hypertension. Med. Sci. Sport. Exer. 2008, 40, 3-8. 
12. Katz, S.D.; Maskin, C.; Jondeau, G.; Cocke, T.; Berkowitz, R.; LeJemtel, T. Near-maximal fractional oxygen extraction by active skeletal muscle in patients with chronic heart failure. J. Appl. Physiol. 2000, 88, 2138-2142.

13. Thomson, S.; Johnson, M. Is systemic oxygen extraction on exercise impaired in pulmonary arterial hypertension? Proceedings of ERS Annual Congress, Barcelona, Spain, 2013.

14. Barst, R.J.; Langleben, D.; Frost, A.; Horn, E.M.; Oudiz, R.; Shapiro, S.; McLaughlin, V.; Hill, N.; Tapson, V.F.; Robbins, I.M.; et al. Sitaxsentan therapy for pulmonary arterial hypertension. Am. J. Respir. Crit. Care Med. 2004, 169, 441-447.

15. Oudiz, R.J.; Barst, R.J.; Hansen, J.E.; Sun, X.G.; Garofano, R.; Wu, X.; Wasserman, K. Cardiopulmonary exercise testing and six-minute walk correlations in pulmonary arterial hypertension. Am. J. Cardiol. 2006, 97, 123-126.

16. Gabler, N.B.; French, B.; Strom, B.L.; Palevsky, H.I.; Taichman, D.B.; Kawut, S.M.; Halpern, S.D. Validation of 6-minute walk distance as a surrogate end point in pulmonary arterial hypertension trials. Circulation 2012, 126, 349-356.

17. Sitbon, O.; Humbert, M.; Nunes, H.; Parent, F.; Garcia, G.; Herve, P.; Rainisio, M.; Simonneau, G. Long-term intravenous epoprostenol infusion in primary pulmonary hypertension: prognostic factors and survival. J. Am. Coll. Cardiol. 2002, 40, 780-788.

18. Lewis, G.D.; Bossone, E.; Naeije, R.; Grunig, E.; Saggar, R.; Lancellotti, P.; Ghio, S.; Varga, J.; Rajagopalan, S.; Oudiz, R.; et al. Pulmonary vascular hemodynamic response to exercise in cardiopulmonary diseases. Circulation 2013, 128, 1470-1479.

19. Naeije, R.; Chesler, N. Pulmonary circulation at exercise. Compr. Physiol. 2012, 2, 711-741.

20. Naeije, R.; Vanderpool, R.; Dhakal, B.P.; Saggar, R.; Saggar, R.; Vachiery, J.L.; Lewis, G.D. Exercise-induced pulmonary hypertension: physiological basis and methodological concerns. Am. J. Respir. Crit. Care Med. 2013, 187, 576-583.

21. Reeves, J.T.; Dempsey, J.A.; Grover, R.F. Pulmonary circulation during exercise. Lung Biol. Health Dis. 1989, 38, 107-133.

22. Kovacs, G.; Berghold, A.; Scheidl, S.; Olschewski, H. Pulmonary arterial pressure during rest and exercise in healthy subjects: A systematic review. Eur. Respir. J. 2009, 34, 888-894.

23. Stringer, W.W.; Hansen, J.E.; Wasserman, K. Cardiac output estimated noninvasively from oxygen uptake during exercise. J. Appl. Physiol. 1997, 82, 908-912.

24. Janicki, J.S.; Weber, K.T.; Likoff, M.J.; Fishman, A.P. The pressure-flow response of the pulmonary circulation in patients with heart failure and pulmonary vascular disease. Circulation 1985, 72, 1270-1278.

25. Provencher, S.; Herve, P.; Sitbon, O.; Humbert, M.; Simonneau, G.; Chemla, D. Changes in exercise haemodynamics during treatment in pulmonary arterial hypertension. Eur. Respir. J. 2008, 32, 393-398.

26. Saggar, R.; Sitbon, O. Hemodynamics in pulmonary arterial hypertension: Current and future perspectives. Am. J. Cardiol. 2012, 110, 9S-15S.

27. Boerrigter, B.G.; Waxman, A.B.; Westerhof, N.; Vonk-Noordegraaf, A.; Systrom, D.M. Measuring central pulmonary pressures during exercise in COPD: How to cope with respiratory effects? Eur. Respir. J. 2013, 43, 1316-1325. 
28. Terkelsen, K.E.; Clark, A.L.; Hillis, W.S. Ventilatory response to erect and supine exercise. Med. Sci. Sport. Exer. 1999, 31, 1429-1432.

29. Castelain, V.; Chemla, D.; Humbert, M.; Sitbon, O.; Simonneau, G.; Lecarpentier, Y.; Herve, P. Pulmonary artery pressure-flow relations after prostacyclin in primary pulmonary hypertension. Am. J. Respir. Crit. Care Med. 2002, 165, 338-340.

30. Borlaug, B.A.; Nishimura, R.A.; Sorajja, P.; Lam, C.S.; Redfield, M.M. Exercise hemodynamics enhance diagnosis of early heart failure with preserved ejection fraction. Circulation 2010, 3, 588-595.

31. Blumberg, F.C.; Arzt, M.; Lange, T.; Schroll, S.; Pfeifer, M.; Wensel, R. Impact of right ventricular reserve on exercise capacity and survival in patients with pulmonary hypertension. Eur. J. Heart Fail. 2013, 15, 771-775.

32. Whyte, K.; Hoette, S.; Herve, P.; Montani, D.; Jais, X.; Parent, F.; Savale, L.; Natali, D.; O'Callaghan, D.S.; Garcia, G.; et al. The association between resting and mild-to-moderate exercise pulmonary artery pressure. Eur. Resp. J. 2012, 39, 313-318.

33. Fowler, R.M.; Maiorana, A.J.; Jenkins, S.C.; Gain, K.R.; O'Driscoll, G.; Gabbay, E. Implications of exercise-induced pulmonary arterial hypertension. Med. Sci. Sport. Exer. 2011, 43, 983-989.

34. Tolle, J.J.; Waxman, A.B.; Van Horn, T.L.; Pappagianopoulos, P.P.; Systrom, D.M. Exerciseinduced pulmonary arterial hypertension. Circulation 2008, 118, 2183-2189.

35. Badesch, D.B.; Champion, H.C.; Sanchez, M.A.; Hoeper, M.M.; Loyd, J.E.; Manes, A.; McGoon, M.; Naeije, R.; Olschewski, H.; Oudiz, R.J.; et al. Diagnosis and assessment of pulmonary arterial hypertension. J. Am. Coll. Cardiol. 2009, 54, S55-S66.

36. Hoeper, M.M.; Bogaard, H.J.; Condliffe, R.; Frantz, R.; Khanna, D.; Kurzyna, M.; Langleben, D.; Manes, A.; Satoh, T.; Torres, F.; et al. Definitions and diagnosis of pulmonary hypertension. J. Am. Coll. Cardiol. 2013, 62, D42-D50.

37. Condliffe, R.; Kiely, D.G.; Peacock, A.J.; Corris, P.A.; Gibbs, J.S.; Vrapi, F.; Das, C.; Elliot, C.A.; Johnson, M.; DeSoyza, J.; et al. Connective tissue disease-associated pulmonary arterial hypertension in the modern treatment era. Am. J. Respir. Crit Care Med. 2009, 179, 151-157.

38. Kovacs, G.; Maier, R.; Aberer, E.; Brodmann, M.; Scheidl, S.; Troster, N.; Hesse, C.; Salmhofer, W.; Graninger, W.; Gruenig, E.; et al. Borderline pulmonary arterial pressure is associated with decreased exercise capacity in scleroderma. Am. J. Respir. Crit Care Med. 2009, 180, 881-886.

39. Saggar, R.; Khanna, D.; Furst, D.E.; Shapiro, S.; Maranian, P.; Belperio, J.A.; Chauhan, N.; Clements, P.; Gorn, A.; Weigt, S.S.; et al. Exercise-induced pulmonary hypertension associated with systemic sclerosis: Four distinct entities. Arthritis Rheum. 2010, 62, 3741-3750.

40. Kovacs, G.; Maier, R.; Aberer, E.; Brodmann, M.; Graninger, W.; Kqiku, X.; Scheidl, S.; Troster, N.; Hesse, C.; Rubin, L.; et al. Pulmonary arterial hypertension therapy may be safe and effective in patients with systemic sclerosis and borderline pulmonary artery pressure. Arthritis Rheum. 2012, 64, 1257-1262.

41. Saggar, R.; Khanna, D.; Shapiro, S.; Furst, D.E.; Maranian, P.; Clements, P.; Abtin, F.; Dua, S.; Belperio, J.; Saggar, R. Brief report: Effect of ambrisentan treatment on exercise-induced pulmonary hypertension in systemic sclerosis: A prospective single-center, open-label pilot study. Arthritis Rheum. 2012, 64, 4072-4077. 
42. Naeije, R. In defence of exercise stress tests for the diagnosis of pulmonary hypertension. Heart 2011, 97, 94-95.

43. Argiento, P.; Vanderpool, R.R.; Mule, M.; Russo, M.G.; D'Alto, M.; Bossone, E.; Chesler, N.C.; Naeije, R. Exercise stress echocardiography of the pulmonary circulation: Limits of normal and sex differences. Chest 2012, 142, 1158-1165.

44. Argiento, P.; Chesler, N.; Mule, M.; D'Alto, M.; Bossone, E.; Unger, P.; Naeije, R. Exercise stress echocardiography for the study of the pulmonary circulation. Eur. Respir. J. 2010, 35, 1273-1278.

45. D'Alto, M.; Ghio, S.; D'Andrea, A.; Pazzano, A.S.; Argiento, P.; Camporotondo, R.; Allocca, F.; Scelsi, L.; Cuomo, G.; Caporali, R.; et al. Inappropriate exercise-induced increase in pulmonary artery pressure in patients with systemic sclerosis. Heart 2011, 97, 112-117.

46. Moller, T.; Peersen, K.; Pettersen, E.; Thaulow, E.; Holmstrom, H.; Fredriksen, P.M. Noninvasive measurement of the response of right ventricular pressure to exercise, and its relation to aerobic capacity. Cardiol. Young 2009, 19, 465-473.

47. Ha, J.W.; Choi, D.; Park, S.; Shim, C.Y.; Kim, J.M.; Mooen, S.H.; Lee, H.J.; Choi, E.Y.; Chung, N. Determinants of exercise-induced pulmonary hypertension in patients with normal $1 \mathrm{ft}$ ventricular ejection fraction. Heart 2009, 95, 490-494.

48. Bossone, E.; Rubenfire, M.; Bach, D.S.; Ricciardi, M.; Armstrong, W.F. Range of tricuspid regurgitation velocity at rest and during exercise in normal adult men: Implications for the diagnosis of pulmonary hypertension. J. Am. Coll. Cardiol. 1999, 33, 1662-1666.

49. Baptista, R.; Serra, S.; Martins, R.; Salvador, M.J.; Castro, G.; Gomes, M.; Santos, L.; Monteiro, P.; da Silva, J.A.; Pego, M.; et al. Exercise-induced pulmonary hypertension in scleroderma patients: A common finding but with elusive pathophysiology. Echocardiography 2013, 30, 378-384.

50. Ha, J.W.; Oh, J.K.; Pellikka, P.A.; Ommen, S.R.; Stussy, V.L.; Bailey, K.R.; Seward, J.B.; Tajik, A.J. Diastolic stress echocardiography: A novel noninvasive diagnostic test for diastolic dysfunction using supine bicycle exercise Doppler echocardiography. J. Am. Soc. Echocardiogr. 2005, 18, 63-68.

51. Reeves, J.T.; Linehan, J.H.; Stenmark, K.R. Distensibility of the normal human lung circulation during exercise. Am. J. Physiol. Lung Cell. Mol. Physiol. 2005, 288, L419-L425.

52. Freeman, M.L.; Landolfo, C.; Safford, R.E.; Keller, C.A.; Heckman, M.G.; Burger, C.D. Noninvasive assessment of right heart function and hemodynamics during exercise in patients with pulmonary arterial hypertension. Southern Med. J. 2013, 106, 141-146.

53. Syyed, R.; Reeves, J.T.; Welsh, D.; Raeside, D.; Johnson, M.K.; Peacock, A. J.The relationship between the components of pulmonary artery pressure remains constant under all conditions in both health and disease. Chest 2008, 133, 633-639.

54. Chemla, D.; Castelain, V.; Provencher, S.; Humbert, M.; Simonneau, G.; Herve, P. Evaluation of various empirical formulas for estimating mean pulmonary artery pressure by using systolic pulmonary artery pressure in adults. Chest 2009, 135, 760-768.

55. Himelman, R.B.; Stulbarg, M.; Kircher, B.; Lee, E.; Kee, L.; Dean, N.C.; Golden, J.; Wolfe, C.L.; Schiller, N.B. Noninvasive evaluation of pulmonary artery pressure during exercise by saline-enhanced Doppler echocardiography in chronic pulmonary disease. Circulation 1989, 79, 863-871. 
56. Christie, J.; Sheldahl, L.M.; Tristani, F.E.; Sagar, K.B.; Ptacin, M.J.; Wann, S. Determination of stroke volume and cardiac output during exercise: Comparison of two-dimensional and Doppler echocardiography, Fick oximetry, and thermodilution. Circulation 1987, 76, 539-547.

57. Burgess, M.I.; Jenkins, C.; Sharman, J.E.; Marwick, T.H. Diastolic stress echocardiography: hemodynamic validation and clinical significance of estimation of ventricular filling pressure with exercise. J. Am. Coll. Cardiol. 2006, 47, 1891-1900.

58. Grunig, E.; Weissmann, S.; Ehlken, N.; Fijalkowska, A.; Fischer, C.; Fourme, T.; Galie, N.; Ghofrani, A.; Harrison, R.E.; Huez, S.; et al. Stress Doppler echocardiography in relatives of patients with idiopathic and familial pulmonary arterial hypertension: Results of a multicenter European analysis of pulmonary artery pressure response to exercise and hypoxia. Circulation 2009, 119, 1747-1757.

59. Reichenberger, F.; Voswinckel, R.; Schulz, R.; Mensch, O.; Ghofrani, H.A.; Olschewski, H.; Seeger, W. Noninvasive detection of early pulmonary vascular dysfunction in scleroderma. Resp. Med. 2009, 103, 1713-1718.

60. Callejas-Rubio, J.L.; Moreno-Escobar, E.; de la Fuente, P.M.; Perez, L.L.; Fernandez, R.R.; Sanchez-Cano, D.; Mora, J.P.; Ortego-Centeno, N. Prevalence of exercise pulmonary arterial hypertension in scleroderma. J. Rheumatol. 2008, 35, 1812-1816.

61. Steen, V.; Chou, M.; Shanmugam, V.; Mathias, M.; Kuru, T.; Morrissey, R. Exercise-induced pulmonary arterial hypertension in patients with systemic sclerosis. Chest 2008, 134, 146-151.

62. Pignone, A.; Mori, F.; Pieri, F.; Oddo, A.; Galeota, G.; Fiori, G.; Del, Rosso A.; Perfetto, F.; Becucci, A.; Livi, R.; et al. Exercise Doppler echocardiography identifies preclinic asymptomatic pulmonary hypertension in systemic sclerosis. Ann. NY Acad. Sci. 2007, 1108, 291-304.

63. Alkotob, M.L.; Soltani, P.; Sheatt, M.A.; Katsetos, M.C.; Rothfield, N.; Hager, W.D.; Foley, R.J.; Silverman, D.I. Reduced exercise capacity and stress-induced pulmonary hypertension in patients with scleroderma. Chest 2006, 130, 176-181.

64. La Gerche, A.; Claessen, G.; Van de Bruaene, A.; Pattyn, N.; Van, Cleemput J.; Gewillig, M.; Bogaert, J.; Dymarkowski, S.; Claus, P.; Heidbuchel, H. Cardiac MRI: a new gold standard for ventricular volume quantification during high-intensity exercise. Circ. Cardiovasc. Imaging 2013, 6, 329-338.

65. van de Veerdonk, M.C.; Kind, T.; Marcus, J.T.; Mauritz, G.J.; Heymans, M.W.; Bogaard, H.J.; Boonstra, A.; Marques, K.M.; Westerhof, N.; Vonk-Noordegraaf, A. Progressive right ventricular dysfunction in patients with pulmonary arterial hypertension responding to therapy. J. Am. Coll. Cardiol. 2011, 58, 2511-2519.

66. Francis, J.M.; Pennell, D.J. Treatment of claustrophobia for cardiovascular magnetic resonance: Use and effectiveness of mild sedation. J. Cardiovasc. Magn. Reson. 2000, 2, 139-141.

67. Groepenhoff, H.; Holverda, S.; Marcus, J.T.; Postmus, P.E.; Boonstra, A.; Vonk-Noordegraaf, A. Stroke volume response during exercise measured by acetylene uptake and MRI. Physiol. Meas. 2007, 28, 1-11.

68. Slonim, N.B.; Ravin, A.; Balchum, O.J.; Dressler, S.H. The effect of mild exercise in the supine position on the pulmonary arterial pressure of five normal human subjects. J. Clin. Invest. 1954, $33,1022-1030$. 
69. Ayotte, B.; Seymour, J.; McIlroy, M.B. A new method for measurement of cardiac output with nitrous oxide. J. Appl. Physiol. 1970, 28, 863-866.

70. McLure, L.E.; Brown, A.; Lee, W.N.; Church, A.C.; Peacock, A.J.; Johnson, M.K. Non-invasive stroke volume measurement by cardiac magnetic resonance imaging and inert gas rebreathing in pulmonary hypertension. Clin. Physiol. Funct. Imaging 2011, 31, 221-226.

71. Lee, W.T.; Brown, A.; Peacock, A.J.; Johnson, M.K. Use of non-invasive haemodynamic measurements to detect treatment response in precapillary pulmonary hypertension. Thorax 2011, 66, 810-814.

72. Hoeper, M.M.; Maier, R.; Tongers, J.; Niedermeyer, J.; Hohlfeld, J.M.; Hamm, M.; Fabel, H. Determination of cardiac output by the Fick method, thermodilution, and acetylene rebreathing in pulmonary hypertension. Am. J. Respir. Crit. Care Med. 1999, 160, 535-541.

73. Bernstein, D.P. Continuous noninvasive real-time monitoring of stroke volume and cardiac output by thoracic electrical bioimpedance. Crit. Care Med. 1986, 14, 898-901.

74. Ferreira, E.M.; Ota-Arakaki, J.S.; Barbosa, P.B.; Siqueira, A.C.; Bravo, D.M.; Kapins, C.E.; Silva, C.M.; Nery, L.E.; Neder, J.A. Signal-morphology impedance cardiography during incremental cardiopulmonary exercise testing in pulmonary arterial hypertension. Clin. Physiol. Funct. Imaging 2012, 32, 343-352.

75. Rich, J.D.; Archer, S.L.; Rich, S. Noninvasive cardiac output measurements in patients with pulmonary hypertension. Eur. Respir. J. 2013, 42, 125-133.

76. Ward, S.A.; Palange, P. Clinical Exercise Testing. In European Respiratory Monograph; European Respiratory Society: Lausanne, Switzerland, 2007; Chapter 40.

77. Janicki, J.S.; Weber, K.T.; Likoff, M.J.; Fishman, A.P. Exercise testing to evaluate patients with pulmonary vascular disease. Am. Rev. Respir. Dis. 1984, 129, S93-S95.

78. D'Alonzo, G.E.; Gianotti, L.A.; Pohil, R.L.; Reagle, R.R.; DuRee, S.L.; Fuentes, F.; Dantzker, D.R. Comparison of progressive exercise performance of normal subjects and patients with primary pulmonary hypertension. Chest 1987, 92, 57-62.

79. Sietsema, K.E. Oxygen uptake kinetics in response to exercise in patients with pulmonary vascular disease. Am. Rev. Respir. Dis. 1992, 145, 1052-1057.

80. Reybrouck, T.; Mertens, L.; Schulze-Neick, I.; Austenat, I.; Eyskens, B.; Dumoulin, M.; Gewillig, M. Ventilatory inefficiency for carbon dioxide during exercise in patients with pulmonary hypertension. Clin. Physiol. 1998, 18, 337-344.

81. Riley, M.S.; Porszasz, J.; Engelen, M.P.; Brundage, B.H.; Wasserman, K. Gas exchange responses to continuous incremental cycle ergometry exercise in primary pulmonary hypertension in humans. Eur. J. Appl. Physiol. 2000, 83, 63-70.

82. Raeside, D.A.; Smith, A.; Brown, A.; Patel, K.R.; Madhok, R.; Cleland, J.; Peacock, A.J. Pulmonary artery pressure measurement during exercise testing in patients with suspected pulmonary hypertension. Eur. Respir. J. 2000, 16, 282-287.

83. Sun, X.G.; Hansen, J.E.; Oudiz, R.J.; Wasserman, K. Exercise pathophysiology in patients with primary pulmonary hypertension. Circulation 2001, 104, 429-435.

84. Mitani, R.; Haraguchi, M.; Takata, S.; Murata, M.; Dairaku, Y.; Kimura, M.; Harada, M.; Tada, T.; Matsuda, M.; Matsuzaki, M. Excessive ventilatory response during exercise in patients with non-hypoxic pulmonary hypertension. Circ. J. 2002, 66, 453-456. 
85. Yasunobu, Y.; Oudiz, R.J.; Sun, X.G.; Hansen, J.E.; Wasserman, K. End-tidal PCO2 abnormality and exercise limitation in patients with primary pulmonary hypertension. Chest 2005, 127, $1637-1646$.

86. Valli, G.; Vizza, C.D.; Onorati, P.; Badagliacca, R.; Ciuffa, R.; Poscia, R.; Brandimarte, F.; Fedele, F.; Serra, P.; Palange, P. Pathophysiological adaptations to walking and cycling in primary pulmonary hypertension. Eur. J. Appl. Physiol. 2008, 102, 417-424.

87. Sun, X.G.; Hansen, J.E.; Oudiz, R.J.; Wasserman, K. Gas exchange detection of exerciseinduced right-to-left shunt in patients with primary pulmonary hypertension. Circulation 2002, $105,54-60$.

88. Markowitz, D.H.; Systrom, D.M. Diagnosis of pulmonary vascular limit to exercise by cardiopulmonary exercise testing. J. Heart Lung Transpl. 2004, 23, 88-95.

89. Yetman, A.T.; Taylor, A.L.; Doran, A.; nd Ivy, D.D. Utility of cardiopulmonary stress testing in assessing disease severity in children with pulmonary arterial hypertension. Am. J. Cardiol. 2005, 95, 697-699.

90. Schwaiblmair, M.; Faul, C.; von, Scheidt W.; Berghaus, T.M. Ventilatory efficiency testing as prognostic value in patients with pulmonary hypertension. BMC Pulm. Med. 2012, 12, 23.

91. Groepenhoff, H.; Vonk-Noordegraaf, A.; van de Veerdonk, M.C.; Boonstra, A.; Westerhof, N.; Bogaard, H.J. Prognostic relevance of changes in exercise test variables in pulmonary arterial hypertension. PLoS One 2013, 8, e72013.

92. Deboeck, G.; Scoditti, C.; Huez, S.; Vachiery, J.L.; Lamotte, M.; Sharples, L.; Melot, C.; Naeije, R. Exercise testing to predict outcome in idiopathic versus associated pulmonary arterial hypertension. Eur. Respir. J. 2012, 40, 1410-1419.

93. Wax, D.; Garofano, R.; Barst, R.J. Effects of long-term infusion of prostacyclin on exercise performance in patients with primary pulmonary hypertension. Chest 1999, 116, 914-920.

94. Wensel, R.; Opitz, C.F.; Ewert, R.; Bruch, L.; Kleber, F.X. Effects of iloprost inhalation on exercise capacity and ventilatory efficiency in patients with primary pulmonary hypertension. Circulation 2000, 101, 2388-2392.

95. Oudiz, R.J.; Roveran, G.; Hansen, J.E.; Sun, X.G.; Wasserman, K. Effect of sildenafil on ventilatory efficiency and exercise tolerance in pulmonary hypertension. Eur. J. Heart Fail. 2007, 9, 917-921.

96. Hansen, J.E.; Sun, X.G.; Yasunobu, Y.; Garafano, R.P.; Gates, G.; Barst, R.J.; Wasserman, K. Reproducibility of cardiopulmonary exercise measurements in patients with pulmonary arterial hypertension. Chest 2004, 126, 816-824.

97. Skalski, J.; Allison, T.G.; Miller, T.D. The safety of cardiopulmonary exercise testing in a population with high-risk cardiovascular diseases. Circulation 2012, 126, 2465-2472.

98. Cappelleri, J.C.; Hwang, L.J.; Mardekian, J.; Mychaskiw, M.A. Assessment of measurement properties of peak $\mathrm{VO}(2)$ in children with pulmonary arterial hypertension. BMC Pulm. Med. 2012, 12, 54.

99. Smith, G.; Reyes, J.T.; Russell, J.L.; Humpl, T. Safety of maximal cardiopulmonary exercise testing in pediatric patients with pulmonary hypertension. Chest 2009, 135, 1209-1214.

100. Deboeck, G.; Niset, G.; Lamotte, M.; Vachiery, J.L.; Naeije, R. Exercise testing in pulmonary arterial hypertension and in chronic heart failure. Eur. Respir. J. 2004, 23, 747-751. 
101. Hansen, J.E.; Ulubay, G.; Chow, B.F.; Sun, X.G.; Wasserman, K. Mixed-expired and end-tidal $\mathrm{CO} 2$ distinguish between ventilation and perfusion defects during exercise testing in patients with lung and heart diseases. Chest 2007, 132, 977-983.

102. Groepenhoff, H.; Westerhof, N.; Jacobs, W.; Boonstra, A.; Postmus, P.E.; Vonk-Noordegraaf, A. Exercise stroke volume and heart rate response differ in right and left heart failure. Eur. J. Heart Fail. 2010, 12, 716-720.

103. Nishio, R.; Tanaka, H.; Tsuboi, Y.; Kinutani, H.; Taniguchi, Y.; Shigeru, M.; Toh, R.; Miura, Y.; Sakai, Y.; Emoto, N.; et al. Differences in hemodynamic parameters and exercise capacity between patients with pulmonary arterial hypertension and chronic heart failure. J. Cardiopulm. Rehabil. 2012, 32, 379-385.

104. Guazzi, M.; Cahalin, L.P.; Arena, R. Cardiopulmonary exercise testing as a diagnostic tool for the detection of left-sided pulmonary hypertension in heart failure. J. Card. Fail. 2013, 19, 461-467.

105. Vonbank, K.; Funk, G.C.; Marzluf, B.; Burian, B.; Ziesche, R.; Stiebellehner, L.; Petkov, V.; Haber, P. Abnormal pulmonary arterial pressure limits exercise capacity in patients with COPD. Wiener Klinische Wochenschrift 2008, 120, 749-755.

106. Boerrigter, B.G.; Bogaard, H.J.; Trip, P.; Groepenhoff, H.; Rietema, H.; Holverda, S.; Boonstra, A.; Postmus, P.E.; Westerhof, N.; Vonk-Noordegraaf, A. Ventilatory and cardiocirculatory exercise profiles in COPD: The role of pulmonary hypertension. Chest 2012, 142, 1166-1174.

107. Glaser, S.; Noga, O.; Koch, B.; Opitz, C.F.; Schmidt, B.; Temmesfeld, B.; Dorr, M.; Ewert, R.; Schaper, C. Impact of pulmonary hypertension on gas exchange and exercise capacity in patients with pulmonary fibrosis. Respir. Med. 2009, 103, 317-324.

108. van der Plas, M.N.; van, Kan C.; Blumenthal, J.; Jansen, H.M.; Wells, A.U.; Bresser, P. Pulmonary vascular limitation to exercise and survival in idiopathic pulmonary fibrosis. Respirology 2014, 19, 269-275.

109. McCabe, C.; Deboeck, G.; Harvey, I.; Ross, R.M.; Gopalan, D.; Screaton, N.; Pepke-Zaba, J. Inefficient exercise gas exchange identifies pulmonary hypertension in chronic thromboembolic obstruction following pulmonary embolism. Thromb. Res. 2013, 132, 659-665.

110. Wensel, R.; Opitz, C.F.; Anker, S.D.; Winkler, J.; Hoffken, G.; Kleber, F.X.; Sharma, R.; Hummel, M.; Hetzer, R.; Ewert, R. Assessment of survival in patients with primary pulmonary hypertension: importance of cardiopulmonary exercise testing. Circulation 2002, 106, 319-324.

111. Wensel, R.; Francis, D.P.; Meyer, F.J.; Opitz, C.F.; Bruch, L.; Halank, M.; Winkler, J.; Seyfarth, H.J.; Glaser, S.; Blumberg, F.; et al. Incremental prognostic value of cardiopulmonary exercise testing and resting haemodynamics in pulmonary arterial hypertension. Int. J. Cardiol. 2013, 167, 1193-1198.

112. Oudiz, R.J.; Midde, R.; Hovenesyan, A.; Sun, X.G.; Roveran, G.; Hansen, J.E.; Wasserman, K. Usefulness of right-to-left shunting and poor exercise gas exchange for predicting prognosis in patients with pulmonary arterial hypertension. Am. J. Cardiol. 2010, 105, 1186-1191.

113. Groepenhoff, H.; Vonk-Noordegraaf, A.; Boonstra, A.; Spreeuwenberg, M.D.; Postmus, P.E.; Bogaard, H.J. Exercise testing to estimate survival in pulmonary hypertension. Med. Sci. Sport. Exer. 2008, 40, 1725-1732. 
114. Dumitrescu, D.; Oudiz, R.J.; Karpouzas, G.; Hovanesyan, A.; Jayasinghe, A.; Hansen, J.E.; Rosenkranz, S.; Wasserman, K. Developing pulmonary vasculopathy in systemic sclerosis, detected with non-invasive cardiopulmonary exercise testing. PLoS One 2010, 5, e14293.

115. Schwaiblmair, M.; Faul, C.; von, Scheidt, W.; Berghaus, T.M. Detection of exercise-induced pulmonary arterial hypertension by cardiopulmonary exercise testing. Clin. Cardiol. 2012, 35, $548-553$.

116. Woods, P.R.; Frantz, R.P.; Taylor, B.J.; Olson, T.P.; Johnson, B.D. The usefulness of submaximal exercise gas exchange to define pulmonary arterial hypertension. J. Heart Lung Transpl. 2011, 30, 1133-1142.

117. Neal, J.E.; Lee, A.S.; Burger, C.D. Submaximal exercise testing may be superior to the sixminute walk test in assessing pulmonary arterial hypertension disease severity. Clin. Respir. J. 2013, in press.

118. Rausch, C.M.; Taylor, A.L.; Ross, H.; Sillau, S.; Ivy, D.D. Ventilatory efficiency slope correlates with functional capacity, outcomes, and disease severity in pediatric patients with pulmonary hypertension. Int. J. Cardiol. 2013, 169, 445-448.

119. Ramos, R.P.; Alencar, M.C.; Treptow, E.; Arbex, F.; Ferreira, E.M.; Neder, J.A. Clinical usefulness of response profiles to rapidly incremental cardiopulmonary exercise testing. Pulm. Med. 2013, 359021.

120. Ramos, R.P.; Arakaki, J.S.; Barbosa, P.; Treptow, E.; Valois, F.M.; Ferreira, E.V.; Nery, L.E.; Neder, J.A. Heart rate recovery in pulmonary arterial hypertension: relationship with exercise capacity and prognosis. Am. Heart J. 2012, 163, 580-588.

121. Baba, R.; Nagashima, M.; Goto, M.; Nagano, Y.; Yokota, M.; Tauchi, N.; Nishibata, K. Oxygen uptake efficiency slope: A new index of cardiorespiratory functional reserve derived from the relation between oxygen uptake and minute ventilation during incremental exercise. J. Am. Coll. Cardiol. 1996, 28, 1567-1572.

122. Van, Laethem C.; Bartunek, J.; Goethals, M.; Nellens, P.; Andries, E.; Vanderheyden, M. Oxygen uptake efficiency slope, a new submaximal parameter in evaluating exercise capacity in chronic heart failure patients. Am. Heart J. 2005, 149, 175-180.

123. Ramos, R.P.; Ota-Arakaki, J.S.; Alencar, M.C.; Ferreira, E.V.; Nery, L.E.; Neder, J.A. Exercise oxygen uptake efficiency slope independently predicts poor outcome in PAH. Eur. Respir. J. 2014, 43, 1510-1512.

124. ATS Statement: Guidelines for the Six-Minute Walk Test. Am. J. Respir. Crit. Care Med. 2002, 166, 111-117.

125. Deboeck, G.; Niset, G.; Vachiery, J.L.; Moraine, J.J.; Naeije, R. Physiological response to the six-minute walk test in pulmonary arterial hypertension. Eur. Respir. J. 2005, 26, 667-672.

126. Ross, R.M.; Murthy, J.N.; Wollak, I.D.; Jackson, A.S. The six minute walk test accurately estimates mean peak oxygen uptake. BMC Pulm. Med. 2010, 10, 31.

127. Miyamoto, S.; Nagaya, N.; Satoh, T.; Kyotani, S.; Sakamaki, F.; Fujita, M.; Nakanishi, N.; Miyatake, K. Clinical correlates and prognostic significance of six-minute walk test in patients with primary pulmonary hypertension. Comparison with cardiopulmonary exercise testing. Am. J. Respir. Criti. Care Med. 2000, 161, 487-492. 
128. Fowler, R.M.; Jenkins, S.C.; Maiorana, A.J.; Gain, K.R.; O'Driscoll, G.; Gabbay, E. Measurement properties of the 6-min walk test in individuals with exercise-induced pulmonary arterial hypertension. Int. Med. J. 2011, 41, 679-687.

129. Chua, R.; Keogh, A.M.; Byth, K.; O'Loughlin, A. Comparison and validation of three measures of quality of life in patients with pulmonary hypertension. Int. Med. J. 2006, 36, 705-710.

130. Savarese, G.; Musella, F.; D'Amore, C.; Losco, T.; Marciano, C.; Gargiulo, P.; Rengo, G.; Dellegrottaglie, S.; Bossone, E.; Leosco, D.; et al. Haemodynamics, exercise capacity and clinical events in pulmonary arterial hypertension. Eur. Respir. J. 2013, 42, 414-424.

131. Garin, M.C.; Highland, K.B.; Silver, R.M.; Strange, C. Limitations to the 6-minute walk test in interstitial lung disease and pulmonary hypertension in scleroderma. J. Rheum. 009, 36, 330-336.

132. Avouac, J.; Kowal-Bielecka, O.; Pittrow, D.; Huscher, D.; Behrens, F.; Denton, C.P.; Foeldvari, I.; Humbert, M.; Matucci-Cerinic, M.; Nash, P.; et al. Validation of the 6 min walk test according to the OMERACT filter: A systematic literature review by the EPOSS-OMERACT group. Ann. Rheum. Dis. 2010, 69, 1360-1363.

133. Lipkin, D.P.; Scriven, A.J.; Crake, T.; Poole-Wilson, P.A. Six minute walking test for assessing exercise capacity in chronic heart failure. Br. Med. J. Clin. Res. Ed. 1986, 292, 653-655.

134. Frost, A.E.; Langleben, D.; Oudiz, R.; Hill, N.; Horn, E.; McLaughlin, V.; Robbins, I.M.; Shapiro, S.; Tapson, V.F.; Zwicke, D.; et al. The 6-min walk test (6MW) as an efficacy endpoint in pulmonary arterial hypertension clinical trials: Demonstration of a ceiling effect. Vasc. Pharmacol. 2005, 43, 36-39.

135. Degano, B.; Sitbon, O.; Savale, L.; Garcia, G.; O'Callaghan, D.S.; Jais, X.; Humbert, M.; Simonneau, G. Characterization of pulmonary arterial hypertension patients walking more than $450 \mathrm{~m}$ in $6 \mathrm{~min}$ at diagnosis. Chest 2010, 137, 1297-1303.

136. Lammers, A.E.; Diller, G.P.; Odendaal, D.; Tailor, S.; Derrick, G.; Haworth, S.G. Comparison of 6-min walk test distance and cardiopulmonary exercise test performance in children with pulmonary hypertension. Arch. Dis. Childh. 2011, 96, 141-147.

137. Wu, G.; Sanderson, B.; Bittner, V. The 6-minute walk test: How important is the learning effect? Am. Heart J. 2003, 146, 129-133.

138. Humbert, M.; Sitbon, O.; Yaici, A.; Montani, D.; O'Callaghan, D.S.; Jais, X.; Parent, F.; Savale, L.; Natali, D.; Gunther, S.; et al. Survival in incident and prevalent cohorts of patients with pulmonary arterial hypertension. Eur. Respir. J. 2010, 36, 549-555.

139. Benza, R.L.; Gomberg-Maitland, M.; Miller, D.P.; Frost, A.; Frantz, R.P.; Foreman, A.J.; Badesch, D.B.; McGoon, M.D. The REVEAL Registry risk score calculator in patients newly diagnosed with pulmonary arterial hypertension. Chest 2012, 141, 354-362.

140. Lee, W.T.; Ling, Y.; Sheares, K.K.; Pepke-Zaba, J.; Peacock, A.J.; Johnson, M.K. Predicting survival in pulmonary arterial hypertension in the UK. Eur. Respir. J. 2012, 40, 604-611.

141. Macchia, A.; Marchioli, R.; Tognoni, G.; Scarano, M.; Marfisi, R.; Tavazzi, L.; Rich, S. Systematic review of trials using vasodilators in pulmonary arterial hypertension: Why a new approach is needed. Am. Heart J. 2010, 159, 245-257.

142. Nickel, N.; Golpon, H.; Greer, M.; Knudsen, L.; Olsson, K.; Westerkamp, V.; Welte, T.; Hoeper, M.M. The prognostic impact of follow-up assessments in patients with idiopathic pulmonary arterial hypertension. Eur. Respir. J. 2012, 39, 589-596. 
143. Van Wolferen, S.A.; Marcus, J.T.; Boonstra, A.; Marques, K.M.; Bronzwaer, J.G.; Spreeuwenberg, M.D.; Postmus, P.E.; Vonk-Noordegraaf, A. Prognostic value of right ventricular mass, volume, and function in idiopathic pulmonary arterial hypertension. Eur. Heart J. 2007, 28, 1250-1257.

144. Fritz, J.S.; Blair, C.; Oudiz, R.J.; Dufton, C.; Olschewski, H.; Despain, D.; Gillies, H.; Kawut, S.M. Baseline and follow-up 6-min walk distance and brain natriuretic peptide predict 2-year mortality in pulmonary arterial hypertension. Chest 2013, 143, 315-323.

145. Galie, N.; Hoeper, M.M.; Humbert, M.; Torbicki, A.; Vachiery, J.L.; Barbera, J.A.; Beghetti, M.; Corris, P.; Gaine, S.; Gibbs, J.S.; et al. Guidelines for the diagnosis and treatment of pulmonary hypertension. Eur. Respir. J. 2009, 34, 1219-1263.

146. Gaine, S.; Simonneau, G. The need to move from 6-minute walk distance to outcome trials in pulmonary arterial hypertension. Eur. Respir. Rev. 2013, 22, 487-494.

147. Savarese, G.; Paolillo, S.; Costanzo, P.; D'Amore, C.; Cecere, M.; Losco, T.; Musella, F.; Gargiulo, P.; Marciano, C.; Perrone-Filardi, P. Do changes of 6-minute walk distance predict clinical events in patients with pulmonary arterial hypertension? A meta-analysis of 22 randomized trials. J. Am. Coll. Cardiol. 2012, 60, 1192-1201.

148. Peacock, A.J.; Crawley, S.; McLure, L.; Blyth, K.; Vizza, C.D.; Poscia, R.; Francone, M.; Iacucci, I.; Olschewski, H.; Kovacs, G.; et al. Changes in right ventricular function measured by cardiac magnetic resonance imaging in patients receiving pulmonary arterial hypertensiontargeted therapy: the EURO-MR study. Circ. Cardiovasc. Imaging 2014, 7, 107-114.

149. Gilbert, C.; Brown, M.C.; Cappelleri, J.C.; Carlsson, M.; McKenna, S.P. Estimating a minimally important difference in pulmonary arterial hypertension following treatment with sildenafil. Chest 2009, 135, 137-142.

150. Mathai, S.C.; Puhan, M.A.; Lam, D.; Wise, R.A. The minimal important difference in the 6minute walk test for patients with pulmonary arterial hypertension. Am. J. Respir. Crit. Care Med. 2012, 186, 428-433.

151. Lee, W-T.N.; Peacock, A.J.; Johnson, M.K. The role of per cent predicted 6-min walk distance in pulmonary arterial hypertension. Eur. Respir. J. 2010, 36, 1294-1301.

152. Wensel, R.; Jilek, C.; Dorr, M.; Francis, D.P.; Stadler, H.; Lange, T.; Blumberg, F.; Opitz, C.; Pfeifer, M.; Ewert, R. Impaired cardiac autonomic control relates to disease severity in pulmonary hypertension. Eur. Respir. J. 2009, 34, 895-901.

153. Minai, O.A.; Gudavalli, R.; Mummadi, S.; Liu, X.; McCarthy, K.; Dweik, R.A. Heart rate recovery predicts clinical worsening in patients with pulmonary arterial hypertension. Am. J. Respir. Crit. Care Med. 2012, 185, 400-408.

154. Paciocco, G.; Martinez, F.J.; Bossone, E.; Pielsticker, E.; Gillespie, B.; Rubenfire, M. Oxygen desaturation on the six-minute walk test and mortality in untreated primary pulmonary hypertension. Eur. Respir. J. 2001, 17, 647-652.

155. Gomberg-Maitland, M.; Huo, D.; Benza, R.L.; McLaughlin, V.V.; Tapson, V.F.; Barst, R.J. Creation of a model comparing 6-minute walk test to metabolic equivalent in evaluating treatment effects in pulmonary arterial hypertension. J. Heart Lung Transpl. 2007, 26, 732-738.

156. Shah, S.J.; Thenappan, T.; Rich, S.; Sur, J.; Archer, S.L. Value of exercise treadmill testing in the risk stratification of patients with pulmonary hypertension. Circulation 2009, 2, 278-286. 
157. Camargo, V.M.; Martins, Bdo C.; Jardim, C.; Fernandes, C.J.; Hovnanian, A.; Souza, R. Validation of a treadmill six-minute walk test protocol for the evaluation of patients with pulmonary arterial hypertension. Jornal Brasileiro De Pneumologia: Publicacao Oficial Da Sociedade Brasileira De Pneumologia E Tisilogia 2009, 35, 423-430.

158. Hsu, C.H.; Glassner, C.; Foreman, A.J.; Agarwal, R.; Benza, R.J.; Frantz, R.P. Treadmill testing improves survival prediction models in pulmonary arterial hypertension. Am. Heart J. 2011, 162, 1011-1017.

159. Scharf, M.L.; Bagga, S. A call to apply the minimal important difference in pulmonary arterial hypertension beyond the flawed 6-minute-walk test. Am. J. Respir. Crit. Care Med. 2013, 187, 659.

160. Irisawa, H.; Takeuchi, K.; Inui, Nt.; Miyakawa, S.; Morishima, Y.; Mizushima, T.; Watanabe, H. Incremental shuttle walk test as a valuable assessmen of exercise performance in patients with pulmonary arterial hypertension. Circ. J. 2013, 78, 215-221.

161. Oga, T.; Nishimura, K.; Tsukino, M.; Hajiro, T.; Ikeda, A.; Izumi, T. The effects of oxitropium bromide on exercise performance in patients with stable chronic obstructive pulmonary disease. A comparison of three different exercise tests. Am. J. Respir. Crit. Care Med. 2000, 161, 1897-1901.

162. Mainguy, V.; Malenfant, S.; Neyron, A.S.; Bonnet, S.; Maltais, F.; Saey, D.; Provencher, S. Repeatability and responsiveness of exercise tests in pulmonary arterial hypertension. Eur. Respir. J. 2013, 42, 425-434.

163. Fox, B.D.; Langleben, D.; Hirsch, A.; Boutet, K.; Shimony, A. Step climbing capacity in patients with pulmonary hypertension. Clin. Res. Cardiol. 2013, 102, 51-61.

164. Bernstein, E.J.; Mandl, L.A.; Gordon, J.K.; Spiera, R.F.; Horn, E.M. Submaximal heart and pulmonary evaluation: A novel noninvasive test to identify pulmonary hypertension in patients with systemic sclerosis. Arthritis Care Res.(Hoboken.) 2013, 65, 1713-1718.

165. Mainguy, V.; Provencher, S.; Maltais, F.; Malenfant, S.; Saey, D. Assessment of daily life physical activities in pulmonary arterial hypertension. PLoS One 2011, 6, e27993.

166. Pugh, M.E.; Buchowski, M.S.; Robbins, I.M.; Newman, J.H.; Hemnes, A.R. Physical activity limitation as measured by accelerometry in pulmonary arterial hypertension. Chest 2012, 142, 1391-1398.

167. Ulrich, S.; Fischler, M.; Speich, R.; Bloch, K.E. Wrist actigraphy predicts outcome in patients with pulmonary hypertension. Respiration 2013, 86, 45-51.

168. Frantz, R.P.; Benza, R.L.; Kjellstrom, B.; Bourge, R.C.; Barst, R.J.; Bennett, T.D.; McGoon, M.D. Continuous hemodynamic monitoring in patients with pulmonary arterial hypertension. J. Heart Lung Transpl. 2008, 27, 780-788.

(C) 2014 by the authors; licensee MDPI, Basel, Switzerland. This article is an open access article distributed under the terms and conditions of the Creative Commons Attribution license (http://creativecommons.org/licenses/by/3.0/). 